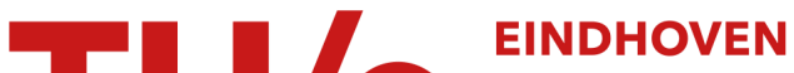 \\ UNIVERSITY OF \\ TECHNOLOGY
}

\section{Flow synthesis of diaryliodonium triflates}

Citation for published version (APA):

Laudadio, G., Gemoets, H. P. L., Noël, T., \& Hessel, V. (2017). Flow synthesis of diaryliodonium triflates. Journal of Organic Chemistry, 82(22), 11735-11741. https://doi.org/10.1021/acs.joc.7b01346

DOI:

10.1021/acs.joc.7b01346

Document status and date:

Published: 17/11/2017

\section{Document Version:}

Typeset version in publisher's lay-out, without final page, issue and volume numbers

\section{Please check the document version of this publication:}

- A submitted manuscript is the version of the article upon submission and before peer-review. There can be important differences between the submitted version and the official published version of record. People interested in the research are advised to contact the author for the final version of the publication, or visit the $\mathrm{DOI}$ to the publisher's website.

- The final author version and the galley proof are versions of the publication after peer review.

- The final published version features the final layout of the paper including the volume, issue and page numbers.

Link to publication

\section{General rights}

Copyright and moral rights for the publications made accessible in the public portal are retained by the authors and/or other copyright owners and it is a condition of accessing publications that users recognise and abide by the legal requirements associated with these rights.

- Users may download and print one copy of any publication from the public portal for the purpose of private study or research.

- You may not further distribute the material or use it for any profit-making activity or commercial gain

- You may freely distribute the URL identifying the publication in the public portal.

If the publication is distributed under the terms of Article 25fa of the Dutch Copyright Act, indicated by the "Taverne" license above, please follow below link for the End User Agreement:

www.tue.nl/taverne

Take down policy

If you believe that this document breaches copyright please contact us at:

openaccess@tue.nl

providing details and we will investigate your claim. 


\title{
Flow Synthesis of Diaryliodonium Triflates
}

\author{
${ }_{2}$ Gabriele Laudadio, ${ }^{\dagger}$ Hannes P. L. Gemoets, ${ }^{\dagger}$ Volker Hessel, ${ }^{\oplus}$ and Timothy Noël*i) \\ 3 Department of Chemical Engineering and Chemistry, Micro Flow Chemistry \& Process Technology, Eindhoven University of \\ 4 Technology, Den Dolech 2, 5612 AZ Eindhoven, The Netherlands
}

\section{S Supporting Information}

6 ABSTRACT: A safe and scalable synthesis of diaryliodonium 7 triflates was achieved using a practical continuous-flow design. A 8 wide array of electron-rich to electron-deficient arenes could readily 9 be transformed to their respective diaryliodonium salts on a gram 10 scale, with residence times varying from 2 to $60 \mathrm{~s}$ ( 44 examples).

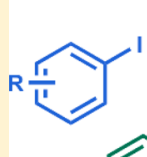

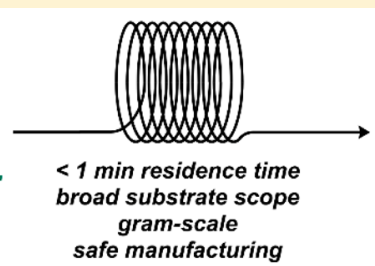

safe manufacturing

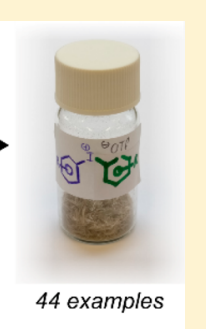

(up to $90 \%$ yield)

\section{$11 \square$ INTRODUCTION}

12 In recent years, the applications of aryl electrophile sources, 13 such as hypervalent iodinated compounds, have become 14 increasingly important in synthetic organic chemistry. ${ }^{1}$ In 15 particular, diaryl- $\lambda^{3}$-iodanes, also known as diaryliodonium salts, 16 have been extensively used in numerous arylation procedures. ${ }^{2}$ 17 Such diaryliodonium salts can be considered as both strong 18 electrophiles and powerful oxidants, which allows chemists to 19 reach higher oxidation states with $\mathrm{Pd}$ or $\mathrm{Cu}$ complexes and to 20 carry out the targeted transformations at milder reaction 21 conditions. $^{3}$ Furthermore, diaryliodonium salts can be used as 22 an electrophilic aryl source to couple with a wide variety of 23 nucleophiles, allowing the preparation of sulfides, ${ }^{4}$ ethers, ${ }^{5}$ 24 amines, $^{6}$ esters, ${ }^{7}$ and nitro compounds ${ }^{8}$ as well as the $\alpha$ 25 arylation on enolates. ${ }^{9}$

26 Given the apparent importance of diaryliodonium salts, many 27 syntheses have been developed to prepare these compounds. ${ }^{10}$ 28 The most practical reaction conditions involve the reaction of 29 iodoarenes with a suitable oxidant to give $\mathrm{I}^{+\mathrm{III}}$ followed by a 30 ligand exchange with an arene. An improved one-pot version 31 was developed by Olofsson et al. using meta-chloroperbenzoic 32 acid ( $m$-CPBA) as the oxidant and trifluoromethanesulfonic 33 acid $(\mathrm{TfOH})$ to yield diaryliodonium triflates directly. ${ }^{11}$ 34 However, such oxidative reaction conditions are typically very 35 exothermic and thus represent a substantial safety risk when 36 carried out on a large scale. Herein, we present a flow synthesis 37 of diaryliodonium triflates which is fast and scalable and 38 provides a broad substrate scope.

\section{RESULTS AND DISCUSSION}

40 To quantify the thermodynamic data of highly exothermic 41 reactions, reaction calorimetry is typically used. ${ }^{12}$ In order to 42 rapidly determine the unknown reaction enthalpy $\left(\Delta H_{\mathrm{R}}\right)$ of the 43 diaryliodonium salt synthesis, we developed an operationally 44 simple adiabatic continuous-flow device that allowed us to 45 calculate $\Delta H_{\mathrm{R}}$ values via in-line $\Delta T$ measurements (see Scheme 46 1c). Hereto, a custom-made glass tube was designed, and the cross-micromixer and microreactor were placed inside. High 47 vacuum was applied to the system in order to create adiabatic 48 conditions (for more details about the setup, see the 49 Supporting Information). Assuming full conversion, we 50 calculated the reaction enthalpy using the following equation, 51 $\Delta H_{\mathrm{R}}=m \times C p \times \Delta T$, where $m$ and $C p$ are the mass and the 52 heat capacity of the solvent, respectively ( $C p$ values of 53 substrates were neglected, which is fair given the dilution). A 54 thermocouple was connected to the T-mixer at the end of the 55 microreactor, which allowed us to have in-line temperature 56 measurements. The calibration of the adiabatic system was 57 performed using the well-known neutralization reaction of 58 sodium hydroxide with hydrochloric acid. ${ }^{13}$ Next, we carried 59 out the synthesis of diphenyliodonium triflate and di- $p$ - 60 tolyliodonium triflate in the adiabatic microfluidic device, and 61 $\Delta T$ values were measured (reactions were performed three 62 times each). With the $C p$ value of DCE known $(C p=129.4 \mathrm{~J} \cdot 63$ $\left.\mathrm{mol}^{-1} \cdot \mathrm{K}^{-1}\right),{ }^{14}$ we were able to directly calculate the respective 64 enthalpy values. Interestingly, very high $\Delta H_{\mathrm{R}}$ values between 65 -160 and $-180 \mathrm{~kJ} / \mathrm{mol}$ were observed, highlighting the need 66 for a safe and reliable method to scale the reaction conditions 67 (Scheme 1). ${ }^{15}$ Such exothermic transformations can be carried 68 out safely in continuous-flow microreactors as the micro- 69 environment results in an excellent heat dissipation rate. ${ }^{16} 70$

We commenced our investigations by designing a suitable 71 continuous-flow setup (Figure 1). Our design consists of three $72 \mathrm{fl}$ individual feeds that allow separation of the hazardous reagents 73 and control of the reaction stoichiometry by adjusting the 74 individual flow rates. The different reagent streams were 75 merged in a cross-micromixer and subsequently introduced in a 76 perfluoroalkoxy capillary reactor (PFA, $750 \mu \mathrm{m}$ i.d., 0.1-3.0 77 $\mathrm{mL}$ ). To avoid microreactor clogging, the mixer and reactor 78

Special Issue: Hypervalent Iodine Reagents

Received: June 13, 2017

Published: July 11, 2017 
Scheme 1. (A) Advantages and Disadvantages of Diaryliodonium Salts, (B) Enthalpy Measurement of the Diaryliodonium Salt Synthesis in an Adiabatic Microreactor, and (C) Flow Setup Used for the Enthalpy Measurements

A

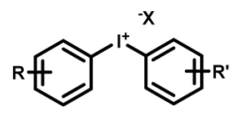

diaryliodonium salts

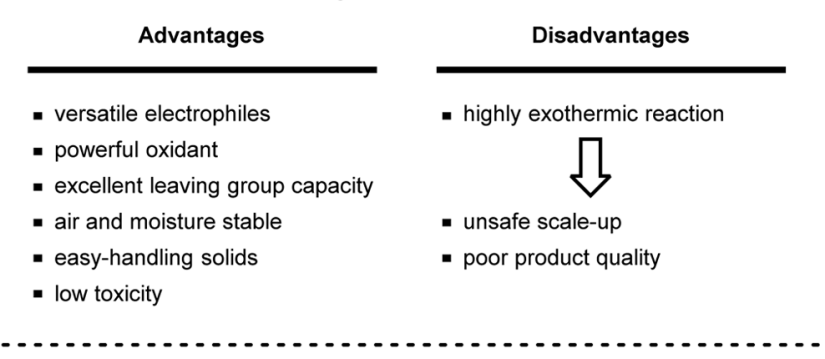

B Enthalpy values for the one-pot synthesis of diaryliodonium triflates

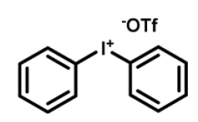

$\Delta \mathrm{H}_{\mathrm{R}}=-160 \mathrm{~kJ} / \mathrm{mol}$

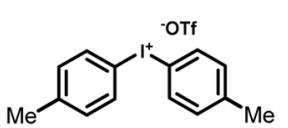

$\Delta \mathrm{H}_{\mathrm{R}}=-180 \mathrm{~kJ} / \mathrm{mol}$
C Adiabatic microflow setup for enthalpy measurements
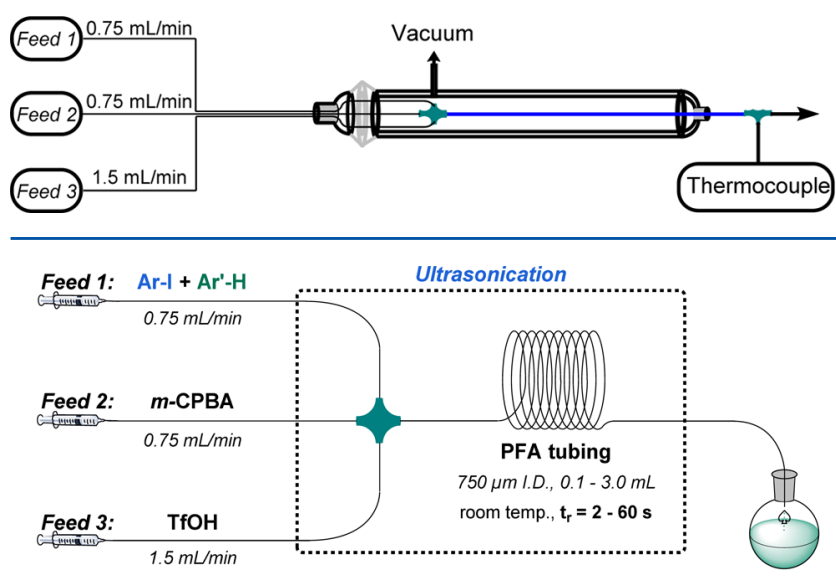

Figure 1. Schematic representation of the microflow setup.

79 were submerged in an ultrasonic bath. ${ }^{17}$ The reaction between 80 4-iodotoluene (1a) and toluene (2a) in the presence of $\mathrm{m}$ $81 \mathrm{CPBA}$ and $\mathrm{TfOH}$ was selected as the benchmark for our 82 reaction optimization studies (see the Supporting Information). 83 Optimal reaction conditions were obtained with 1.1 equiv of $2 \mathrm{a}$ 84 and $m$-CPBA, and 2 equiv of TfOH and dichloroethane (DCE) 85 as the solvent in a $100 \mu \mathrm{L}$ microreactor. The reaction was 86 remarkably fast and was completed within $2 \mathrm{~s}$ residence time. 87 Notably, the desired di-p-tolyliodonium triflate $3 a$ could be 88 obtained on a gram scale $(2.04 \mathrm{~g}, 89 \%)$ in excellent yield as 89 pure and simple to handle crystals (Figure 2). Analogous batch 90 experiments resulted in a lower yield (69\% yield) of 3a as an 91 inferior-quality powder precipitate.

92 With the optimized conditions in hand, we sought to 93 demonstrate the generality of our flow protocol (Table 1). 94 Within a $2 \mathrm{~s}$ residence time, a diverse set of both symmetrical 95 and unsymmetrical diaryliodonium triflates was synthesized in 96 fair to excellent yield on a gram scale (5-10 mmol scale).

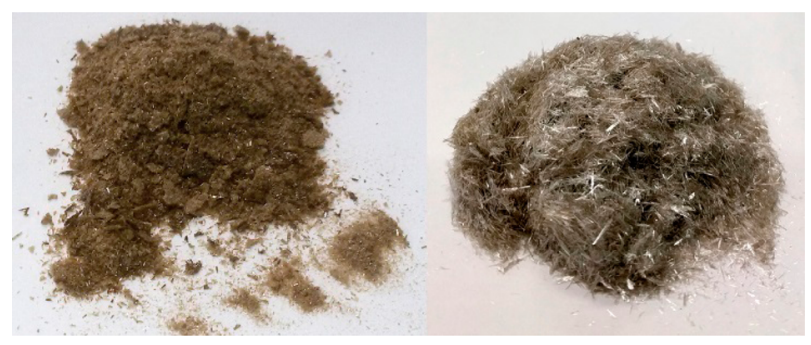

Figure 2. Comparison of the solids obtained after precipitation of di-ptolyliodonium triflate (3a) produced either in batch (left) or flow (right).

Table 1. Scope of Diaryliodonium Triflates Using ElectronNeutral and Electron-Rich Aryl Iodides ${ }^{a}$

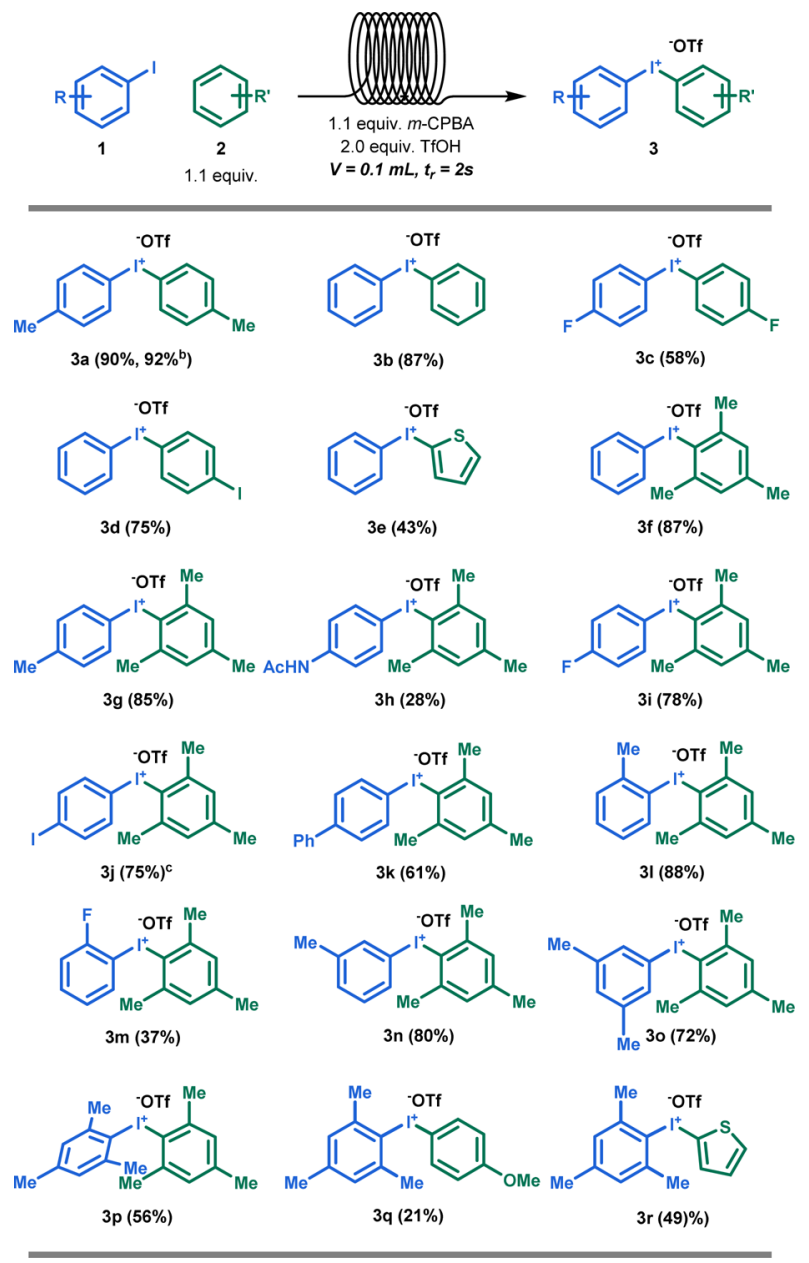

${ }^{a}$ Reaction conditions. Feed 1: $5.0 \mathrm{mmol}$ of aryl iodide (1), $5.5 \mathrm{mmol}$ of arene (2) in $25 \mathrm{~mL}$ of DCE. Feed 2: $5.5 \mathrm{mmol}$ of $m$-CPBA in $25 \mathrm{~mL}$ of DCE. Feed 3: $10 \mathrm{mmol}$ of TfOH in $50 \mathrm{~mL}$ of DCE. Throughput distribution, feed $1 /$ feed $2 /$ feed 3 was 1:1:2. ${ }^{b} 10 \mathrm{mmol}$ scale reaction.

Symmetrical diaryliodonium triflates were readily produced in 97 good to excellent yields (3a-3c). Using different (hetero)- 98 arenes, unsymmetrical diaryliodonium salts were synthesized 99 (3d, 3e). Furthermore, the use of sterically hindered mesitylene 100 was well-tolerated, providing access to a diverse set of aryl 101 mesityliodonium triflates $(\mathbf{3} \mathbf{f}-\mathbf{3 p} \mathbf{p})$. These compounds are of 102 high interest in cross-coupling and $\mathrm{C}-\mathrm{H}$ arylation chemistry 103 because they allow selective transfer of the functionalized aryl 104 groups to the substrate. Aryl iodides bearing strong electron- 105 
106 donating substituents (e.g., anisoles) or electron-rich hetero107 aromatic iodides (e.g., thiophene) were incompatible with the 108 reaction conditions. However, these diaryliodonium triflates 109 could be accessed when using the mesityl iodide with the 110 corresponding (hetero)arenes, albeit in a lower yield (3q and $1113 \mathbf{3}$ ).

112 Aryl iodides with electron-withdrawing functional groups 113 proved particularly challenging. However, after a minor 114 reoptimization of the reaction conditions (see the Supporting 115 Information), it was found that these compounds could be 116 obtained in good yields by increasing the reactor volume to 3 $117 \mathrm{~mL}$ and using an excess of $m$-CPBA (1.3 equiv) and TfOH (3.0 118 equiv). Aryl iodides bearing ortho, meta, and para electron119 withdrawing substituents (e.g., halogens, nitro, esters, ketones) 120 were all well-tolerated, yielding the targeted diaryliodonium 121 triflates in synthetically useful yields (32-90\% yield) (Table 2). 122 Also, 3-iodopyridine (3x and 3ai) and 1-iodoanthraquinone 123 (3s) could be subjected to the flow conditions, resulting in the 124 desired compounds in fair yields (19-47\% yield).

125 Finally, with the aim of developing a flow protocol utilizing 126 cheap and easily available starting materials, we chose to oxidize 127 simple arenes using molecular iodine to yield the corresponding 128 symmetrical diaryliodonium triflates. Optimal results were

Table 2. Scope of Diaryliodonium Triflates with ElectronDeficient Substrates ${ }^{a}$
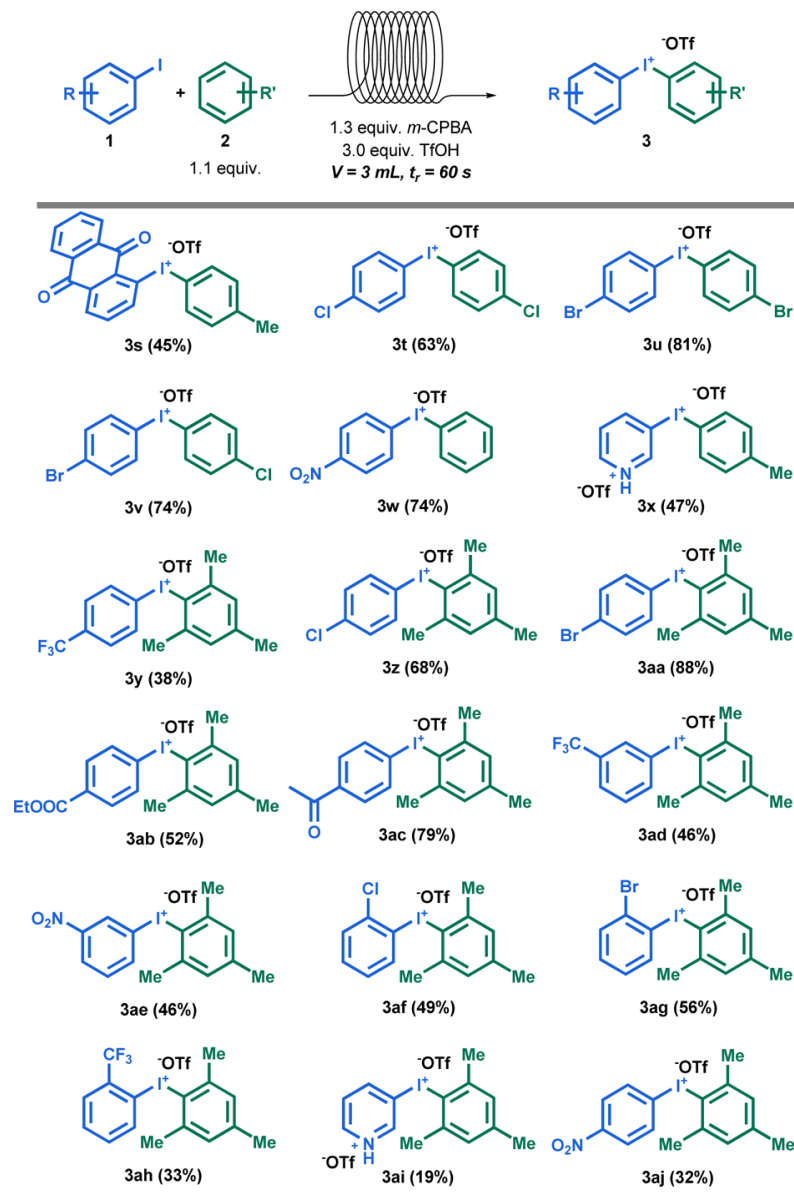

${ }^{a}$ Reaction conditions. Feed 1: $5.0 \mathrm{mmol}$ of $1,5.5 \mathrm{mmol}$ of 2 in $25 \mathrm{~mL}$ of DCE. Feed 2: $6.5 \mathrm{mmol}$ of $m$-CPBA in $25 \mathrm{~mL}$ of DCE. Feed 3: 15 $\mathrm{mmol}$ of $\mathrm{TfOH}$ in $50 \mathrm{~mL}$ of DCE. Throughput distribution, feed 1/ feed 2 /feed 3 was 1:1:2. obtained using iodine as the limiting reagent along with 3129 equiv of $m$-CPBA, $4.1-10$ equiv of arene, and 5 equiv of TfOH 130 (see the Supporting Information). Moderate to excellent yields 131 were obtained for the synthesis of symmetrical diaryliodonium 132 salts (38-90\%) (Table 3). In most cases, the para-para- $133 \mathrm{t} 3$

Table 3. Scope of Symmetric Diaryliodonium Triflates Derived from Arenes and Molecular Iodine ${ }^{a}$
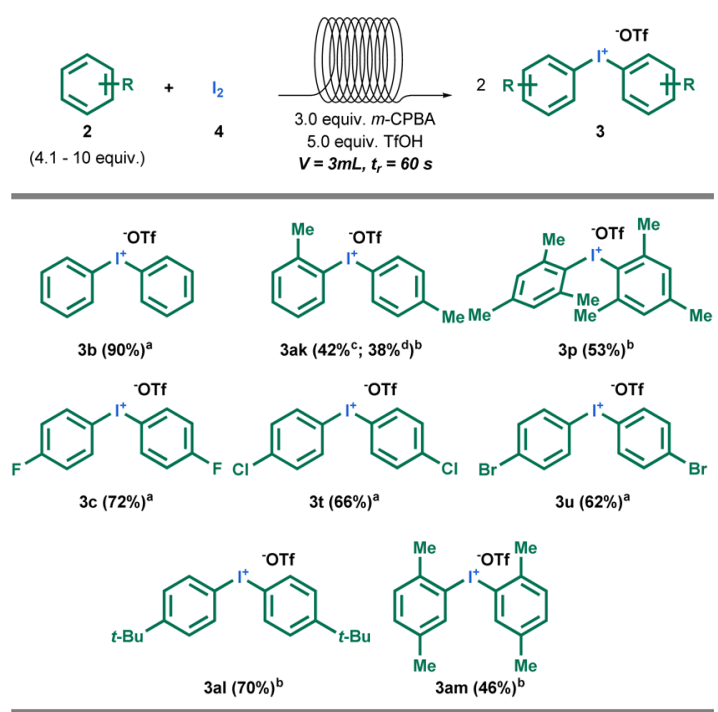

${ }^{a}$ Reaction conditions. Feed 1: $2.0 \mathrm{mmol}$ of 4, 10 equiv of 2 in $10 \mathrm{~mL}$ of DCE. Feed 2: $6.0 \mathrm{mmol}$ of $m$-CPBA in $10 \mathrm{~mL}$ of DCE. Feed 3: 10 $\mathrm{mmol}$ of $\mathrm{TfOH}$ in $10 \mathrm{~mL}$ of DCE. Syringe pumps were used to add reagents to the reactor. Throughput distribution, feed $1 /$ feed $2 /$ feed 3 was 1:1:2. ${ }^{b} 4.1$ equiv of arene was used. ${ }^{c}$ Selectivity at room temperature: ortho-para $90 \%$, para-para $5 \%$, and ortho-ortho $5 \%$. ${ }^{d}$ Selectivity at $0{ }^{\circ} \mathrm{C}$ : ortho-para $>96 \%$.

substituted diaryliodonium analogues were obtained as the only 134 regioisomer. However, when using toluene as the substrate, 135 several other regioisomers were obtained with the ortho-para 136 isomer being the most abundant (3ak). However, the selectivity 137 could be completely tuned toward the ortho-para isomer by 138 decreasing the reaction temperature to $0{ }^{\circ} \mathrm{C}$.

139

\section{CONCLUSIONS}

140

In summary, we have developed a fast, scalable, and safe 141 continuous-flow protocol to prepare various symmetrical and 142 unsymmetrical diaryliodonium triflates. Our protocol displayed 143 a broad substrate scope of electron-rich to electron-deficient 144 substrates (44 examples, yields up to 90\%). Notably, the 145 reaction could be completed in a matter of seconds, allowing 146 the preparation the diaryliodonium triflates on a gram scale 147 with excellent purity in a time-efficient fashion. We believe that 148 the developed flow protocol will find widespread use in both 149 academia and industry given the synthetic relevance of 150 diaryliodonium salts.

\section{EXPERIMENTAL SECTION}

152

All reagents and solvents were used as received without further 153 purification. All capillary tubing and microfluidic fittings were 154 purchased from IDEX Health \& Science. Used syringes were from 155 BD Discardit II or NORM-JECT. Syringe pumps were purchased from 156 Chemix Inc. model Fusion 200 Touch. Used ultrasonicator was VWR 157 USC300T. ${ }^{1} \mathrm{H}(400 \mathrm{MHz}),{ }^{13} \mathrm{C}(100 \mathrm{MHz})$, and ${ }^{19} \mathrm{~F}(376 \mathrm{MHz}){ }_{158}$ NMR spectra were recorded at ambient temperature using a Bruker 159 Avance 400 or Mercury 400 spectrometer. ${ }^{1} \mathrm{H}$ NMR spectra are 160 
161 reported in parts per million (ppm) downfield relative to $\mathrm{CDCl}_{3}(7.26$ $162 \mathrm{ppm})$ and DMSO- $d_{6}(2.50 \mathrm{ppm})$; all ${ }^{13} \mathrm{C}\left\{{ }^{1} \mathrm{H}\right\}$ NMR spectra are 163 reported in ppm relative to $\mathrm{CDCl}_{3}(77.2 \mathrm{ppm})$ and DMSO- $d_{6}(39.52$ $164 \mathrm{ppm}$ ). HRMS (ESI/APCI multimode ionization source, TOF-MSD 165 analyzer) was measured with direct infusion in a 50:50 flow of $5 \mathrm{mM}$ $166 \mathrm{NH}_{4} \mathrm{OAc}$ in water/MeOH. NMR data were processed using the 167 MestReNova 9.0.1 software package. Known products were 168 characterized by comparison to the corresponding ${ }^{1} \mathrm{H}$ NMR and ${ }^{13} \mathrm{C}$ 169 NMR from literature. Melting points were determined with a Buchi B170540 capillary melting point apparatus in open capillaries and are 171 uncorrected. The names of all products were generated using the 172 PerkinElmer ChemBioDraw Ultra v.12.0.2 software package.

\section{General Procedure for the Diaryliodonium Salt Synthesis} 174 with Electron-Neutral and Electron-Rich Substrates (GP1). A 25 $175 \mathrm{~mL}$ oven-dried volumetric flask was charged with 4-iodotoluene (1a, $1761.09 \mathrm{~g}, 5.0 \mathrm{mmol}$ ) and toluene (2a, $506 \mathrm{mg}, 5.5 \mathrm{mmol})$. Next, a second $17725 \mathrm{~mL}$ oven-dried volumetric flask was charged with meta178 chloroperbenzoic acid $(\leq 77 \%)(1.24 \mathrm{~g}, 5.5 \mathrm{mmol})$. Both the flasks 179 were fitted with a septum and were degassed by alternating vacuum 180 and argon backfill. Dichloroethane was added via syringe to make a $18125.0 \mathrm{~mL}$ solution in both flasks. Both the solutions were charged in 30 $182 \mathrm{~mL}$ NORM-JECT syringes and were fitted to a single syringe pump. 183 Afterwards, a $50 \mathrm{~mL}$ oven-dried volumetric flask fitted with a septum 184 and was degassed by alternating vacuum and argon backfill and 185 charged with $20 \mathrm{~mL}$ of dichloroethane. Trifluoromethanesulfonic acid $186(0.9 \mathrm{~mL}, 10.0 \mathrm{mmol})$ was added carefully with a syringe, and 187 dichloroethane was added via syringe to make a $50.0 \mathrm{~mL}$ solution. The 188 solution was charged in a $60 \mathrm{~mL}$ NORM-JECT syringe and fitted to a 189 second syringe pump. All syringes were connected to a PEEK cross190 mixer $(500 \mu \mathrm{m}$ i.d.) and subsequently connected to the inlet of the 0.1 $191 \mathrm{~mL}$ PFA capillary tubing $(750 \mu \mathrm{m}$ i.d.). The cross-mixer and 192 microreactor were submerged in a sonication bath, and sonication 193 was applied during operation. The first syringe pump (containing two 194 syringes) was operated at $2 \times 0.75 \mathrm{~mL} / \mathrm{min}$, and the second syringe 195 pump was operated at $1.5 \mathrm{~mL} / \mathrm{min}$ (total $3 \mathrm{~mL} / \mathrm{min}$ flow rate, $2 \mathrm{~s}$ 196 residence time). The outlet of the reactor was fitted to an argon-filled 197 round-bottom flask with septum via a needle connection. An argon198 filled balloon was attached in order to ensure a constant pressure. The 199 reaction mixture was evaporated under reduced pressure at the 200 rotavap. Residue was dissolved in diethyl ether and evaporated again at 201 the rotavap. This procedure was repeated three times, and then the 202 residue was dissolved in a minimum amount of acetone, followed by 203 addition of diethyl ether until a cloudy solution was obtained. Next, 204 the resulting mixture was kept in the freezer $\left(-26^{\circ} \mathrm{C}\right)$ overnight. 205 Formed crystals were filtered off and washed with a minimum of 206 diethyl ether.

\section{General Procedure for the Diaryliodonium Salt Synthesis} 208 with Electron-Deficient Substrates (GP2). A $25 \mathrm{~mL}$ oven-dried 209 volumetric flask was charged with 4-iodonitrobenzene (1b, $1.25 \mathrm{~g}, 5.0$ $210 \mathrm{mmol}$ ) and mesitylene $(\mathbf{2 b}, 0.76 \mathrm{~mL}, 5.5 \mathrm{mmol})$. Next, a second 25 $211 \mathrm{~mL}$ oven-dried volumetric flask was charged with meta-chloroperben212 zoic acid $(\leq 77 \%)(1.5 \mathrm{~g}, 6.5 \mathrm{mmol})$. Both the flasks were fitted with a 213 septum and were degassed by alternating vacuum and argon backfill. 214 Dichloroethane was added via syringe to make a $25.0 \mathrm{~mL}$ solution in 215 both flasks. Both the solutions were charged in $30 \mathrm{~mL}$ NORM-JECT 216 syringes and were fitted to a single syringe pump. Afterwards, a $50 \mathrm{~mL}$ 217 oven-dried volumetric flask was fitted with a septum and was degassed 218 by alternating vacuum and argon backfill and charged with $40 \mathrm{~mL}$ of 219 dichloroethane. Trifluoromethanesulfonic acid $(1.3 \mathrm{~mL}, 15 \mathrm{mmol})$ was 220 added carefully with a syringe, and dichloroethane was added via 221 syringe to make a $50.0 \mathrm{~mL}$ solution. The solution was charged in a 60 $222 \mathrm{~mL}$ NORM-JECT syringe and fitted to a second syringe pump. All 223 syringes were connected to a PEEK cross-mixer $(500 \mu \mathrm{m}$ i.d.) and 224 subsequently connected to the inlet of the $3.0 \mathrm{~mL}$ PFA capillary tubing $225(750 \mu \mathrm{m}$ i.d.). The cross-mixer and microreactor were submerged in a 226 sonication bath, and sonication was applied during operation. The first 227 syringe pump (containing two syringes) was operated at $2 \times 0.75 \mathrm{~mL} /$ $228 \mathrm{~min}$, and the second syringe pump was operated at $1.5 \mathrm{~mL} / \mathrm{min}$ (total $2293 \mathrm{~mL} / \mathrm{min}$ flow rate, $60 \mathrm{~s}$ residence time). The outlet of the reactor 230 was fitted to an argon-filled round-bottom flask with septum via a needle connection. An argon-filled balloon was attached in order to 231 ensure a constant pressure. The reaction mixture was evaporated 232 under reduced pressure at the rotavap. Residue was dissolved in 233 diethyl ether and evaporated again at the rotavap. This procedure was 234 repeated three times, and then the residue was dissolved in a minimum 235 amount of acetone, followed by addition of diethyl ether until a cloudy 236 solution was obtained. Next, the resulting mixture was kept in the 237 freezer $\left(-26{ }^{\circ} \mathrm{C}\right)$ overnight. Formed crystals were filtered off and 238 washed with a minimum of diethyl ether.

239

General Procedure for the Diaryliodonium Salt Synthesis 240 with lodine (GP3). A $10 \mathrm{~mL}$ oven-dried volumetric flask was charged 241 with iodine $(4,507 \mathrm{mg}, 2 \mathrm{mmol})$ and the arene $(2,8.2-20 \mathrm{mmol}) .242$ Next, a second $10 \mathrm{~mL}$ oven-dried volumetric flask was charged with 243 meta-chloroperbenzoic acid ( $\leq 77 \%)(1.5 \mathrm{~g}, 6 \mathrm{mmol})$. Both the flasks 244 were fitted with a septum and were degassed by alternating vacuum 245 and argon backfill. Dichloroethane was added via syringe to make a 10246 $\mathrm{mL}$ solution in both flasks. Both the solutions were charged in $10 \mathrm{~mL} 247$ NORM-JECT syringes and were fitted to a single syringe pump. 248 Afterwards, a $25 \mathrm{~mL}$ oven-dried volumetric flask was fitted with a 249 septum and was degassed by alternating vacuum and argon backfill and 250 charged with around $15 \mathrm{~mL}$ of dichloroethane. Trifluoromethane- 251 sulfonic acid $(0.9 \mathrm{~mL}, 10.0 \mathrm{mmol})$ was added carefully with a syringe, 252 and dichloroethane was added via syringe to make a $20.0 \mathrm{~mL}$ solution. 253 The solution was charged in a $20 \mathrm{~mL}$ NORM-JECT syringe and fitted 254 to a second syringe pump. All syringes were connected to a PEEK 255 cross-mixer $(500 \mu \mathrm{m}$ i.d.) and subsequently connected to the inlet of 256 the $3 \mathrm{~mL}$ PFA capillary tubing $(750 \mu \mathrm{m}$ i.d.). The cross-mixer and 257 microreactor were submerged in a sonication bath, and sonication was 258 applied during operation. The first syringe pump (containing two 259 syringes) was operated at $2 \times 0.75 \mathrm{~mL} / \mathrm{min}$, and the second syringe 260 pump was operated at $1.5 \mathrm{~mL} / \mathrm{min}$ (total $3 \mathrm{~mL} / \mathrm{min}$ flow rate, $60 \mathrm{~s} 261$ residence time). The outlet of the reactor was fitted to an argon-filled 262 round-bottom flask with septum via a needle connection. An argon- 263 filled balloon was attached in order to ensure a constant pressure. The 264 reaction mixture was evaporated under reduced pressure at the 265 rotavap. Residue was dissolved in diethyl ether and evaporated again at 266 the rotavap. This procedure was repeated five times, and then the 267 residue was dissolved in a minimum amount of acetone, followed by 268 addition of diethyl ether until a cloudy solution was obtained. Next, 269 the resulting mixture was kept in the freezer $\left(-26{ }^{\circ} \mathrm{C}\right)$ overnight. 270 Formed crystals were filtered off and washed with a minimum of 271 diethyl ether.

272

Di-p-tolyliodonium Trifluoromethanesulfonate (3a). ${ }^{18}$ GP1 was 273 used on a $5 \mathrm{mmol}$ scale. Purification by recrystallization in diethyl 274 ether afforded the product as gray solids (2.04g, 89\%): mp 131-133 275 ${ }^{\circ} \mathrm{C}\left(\right.$ lit. $\left.^{18} 121-123^{\circ} \mathrm{C}\right) ;{ }^{1} \mathrm{H}$ NMR $(400 \mathrm{MHz}$, DMSO-d $) \delta 8.15-8.05276$ (m, 4H), $7.31(\mathrm{~d}, J=8.1 \mathrm{~Hz}, 4 \mathrm{H}), 2.32(\mathrm{~s}, 6 \mathrm{H}) ;{ }^{13} \mathrm{C}\left\{{ }^{1} \mathrm{H}\right\}$ NMR $(101277$ MHz, DMSO- $\left.d_{6}\right) \delta 142.5,135.0,132.3,120.8(\mathrm{q}, J=322.3 \mathrm{~Hz}), 113.1,278$ 20.8 .

Diphenyliodonium Trifluoromethanesulfonate (3b). ${ }^{19}$ GP1 was 280 used on a $5 \mathrm{mmol}$ scale. Purification by recrystallization in diethyl 281 ether afforded the product as off-white solids (1.89 g, 88\%). GP3 was 282 used on a $4 \mathrm{mmol}$ scale. Purification by recrystallization in diethyl 283 ether afforded the product as off-white solids (1.55 g, 90\%): $\mathrm{mp} 169-284$ $173{ }^{\circ} \mathrm{C}$ (lit. $\left.{ }^{19} 172-174{ }^{\circ} \mathrm{C}\right) ;{ }^{1} \mathrm{H}$ NMR (400 MHz, DMSO-d $\left.)_{6}\right) \delta 8.27285$ $(\mathrm{d}, J=8.0 \mathrm{~Hz}, 4 \mathrm{H}), 7.64(\mathrm{t}, J=7.4 \mathrm{~Hz}, 2 \mathrm{H}), 7.52(\mathrm{t}, J=7.7 \mathrm{~Hz}, 4 \mathrm{H}) ; 286$ ${ }^{13} \mathrm{C}\left\{{ }^{1} \mathrm{H}\right\}$ NMR $\left(101 \mathrm{MHz}, \mathrm{DMSO}-d_{6}\right) \delta 135.2,132.1,131.8,120.8(\mathrm{q}, 287$ $J=322.3 \mathrm{~Hz}), 116.5$.

Bis(4-fluorophenyl)iodonium Trifluoromethanesulfonate $(3 c)^{2 c}{ }_{289}^{288}$ GP1 was used on a $5 \mathrm{mmol}$ scale. Purification by recrystallization in 290 diethyl ether afforded the product as gray solids (1.35 g, 58\%). GP3 291 was used on a $4 \mathrm{mmol}$ scale. Purification by recrystallization in diethyl 292 ether afforded the product as gray solids (1.34 g, 72\%): mp 168-170 293 ${ }^{\circ} \mathrm{C}$ (lit. $\left.{ }^{2 \mathrm{c}} 168-170{ }^{\circ} \mathrm{C}\right) ;{ }^{1} \mathrm{H}$ NMR $(400 \mathrm{MHz}$, DMSO-d 6 ) $\delta 8.39-8.22294$ (m, 4H), $7.42(\mathrm{t}, J=8.9 \mathrm{~Hz}, 4 \mathrm{H}) ;{ }^{13} \mathrm{C}\left\{{ }^{1} \mathrm{H}\right\}$ NMR (101 MHz, DMSO- 295 $\left.d_{6}\right) \delta 164.4(\mathrm{~d}, J=251.5 \mathrm{~Hz}), 138.4(\mathrm{~d}, J=9.1 \mathrm{~Hz}), 122.7(\mathrm{q}, J=322.6296$ $\mathrm{Hz}), 119.8,119.6,111.6(\mathrm{~d}, J=3.0 \mathrm{~Hz}) ;{ }^{19} \mathrm{~F}$ NMR (376 MHz, DMSO- 297 $\left.d_{6}\right) \delta-77.75,-106.60(\mathrm{tt}, J=9.0,5.0 \mathrm{~Hz})$.

(4-lodophenyl)(phenyl)iodonium Trifluoromethanesulfonate 299 (3d). ${ }^{19}$ GP1 was used on a $5 \mathrm{mmol}$ scale. Purification by 300 
301 recrystallization in diethyl ether afforded the product as off-white 302 solids ( 2.09 g, $75 \%$ ): mp $144-148{ }^{\circ} \mathrm{C}$ (lit. $\left.{ }^{19} 146-148{ }^{\circ} \mathrm{C}\right) ;{ }^{1} \mathrm{H}$ NMR $303\left(400 \mathrm{MHz}, \mathrm{DMSO}-d_{6}\right) \delta 8.24(\mathrm{~d}, J=7.0 \mathrm{~Hz}, 2 \mathrm{H}), 8.00(\mathrm{~d}, J=8.5 \mathrm{~Hz}$, $3042 \mathrm{H}), 7.90(\mathrm{~d}, J=8.5 \mathrm{~Hz}, 2 \mathrm{H}), 7.68(\mathrm{t}, J=7.4 \mathrm{~Hz}, 1 \mathrm{H}), 7.54(\mathrm{t}, J=7.8$ $305 \mathrm{~Hz}, 2 \mathrm{H}) ;{ }^{13} \mathrm{C}\left\{{ }^{1} \mathrm{H}\right\}$ NMR (101 MHz, DMSO- $\left.d_{6}\right) \delta 140.39,136.75$, $306135.16,132.14,131.80,120.67$ (q, $J=322.4 \mathrm{~Hz}), 116.67,115.83$, $307 \quad 100.28$

308 Phenyl(thiophen-2-yl)iodonium Trifluoromethanesulfonate $309(3 e){ }^{2 C}$ GP1 was used on a $5 \mathrm{mmol}$ scale. Purification by 310 recrystallization in diethyl ether afforded the product as light brown 311 solids (937 mg, 43\%): mp $143-146{ }^{\circ} \mathrm{C}$ (lit. $\left.{ }^{2 \mathrm{c}} 144-146{ }^{\circ} \mathrm{C}\right) ;{ }^{1} \mathrm{H}$ NMR $312\left(400 \mathrm{MHz}, \mathrm{DMSO}-d_{6}\right) \delta 8.29-8.21(\mathrm{~m}, 2 \mathrm{H}), 8.07(\mathrm{dd}, J=3.8,1.3 \mathrm{~Hz}$, $3131 \mathrm{H}), 7.97(\mathrm{dd}, J=5.3,1.3 \mathrm{~Hz}, 1 \mathrm{H}), 7.71-7.63(\mathrm{~m}, 1 \mathrm{H}), 7.58-7.47$ $314(\mathrm{~m}, 2 \mathrm{H}), 7.18(\mathrm{dd}, J=5.3,3.8 \mathrm{~Hz}, 1 \mathrm{H}) ;{ }^{13} \mathrm{C}\left\{{ }^{1} \mathrm{H}\right\}$ NMR $(101 \mathrm{MHz}$, 315 DMSO- $\left.d_{6}\right) \delta 140.9,137.8,135.1,132.6,132.2,130.1,121.2(\mathrm{q}, J=$ $316322.2 \mathrm{~Hz}), 119.8,101.2$.

317 Mesityl(phenyl)iodonium Trifluoromethanesulfonate (3f). ${ }^{20}$ GP1 318 was used on a $5 \mathrm{mmol}$ scale. Purification by recrystallization in diethyl 319 ether afforded the product as off-white solids (2.05g, 87\%): $\mathrm{mp} 148-$ $320150{ }^{\circ} \mathrm{C}\left(\right.$ lit. $\left.^{20} 137-138{ }^{\circ} \mathrm{C}\right) ;{ }^{1} \mathrm{H}$ NMR $\left(400 \mathrm{MHz}\right.$, DMSO-d $\left.d_{6}\right) \delta 8.06-$ $3217.94(\mathrm{~m}, 2 \mathrm{H}), 7.69-7.60(\mathrm{~m}, 2 \mathrm{H}), 7.51(\mathrm{t}, J=7.8 \mathrm{~Hz}, 2 \mathrm{H}), 7.22(\mathrm{~s}$, $3222 \mathrm{H}), 2.62(\mathrm{~s}, 6 \mathrm{H}), 2.29(\mathrm{~s}, 3 \mathrm{H}) ;{ }^{13} \mathrm{C}\left\{{ }^{1} \mathrm{H}\right\}$ NMR (101 MHz, DMSO$\left.323 d_{6}\right) \delta 143.1,141.6,134.5,131.9,129.8,122.6,120.7(\mathrm{q}, J=322.3 \mathrm{~Hz})$, $324114.5,26.3,20.5$.

325 Mesityl(p-tolyl)iodonium Trifluoromethanesulfonate $(3 \boldsymbol{g}) .^{20} \mathrm{GP} 1$ 326 was used on a $5 \mathrm{mmol}$ scale. Purification by recrystallization in diethyl 327 ether afforded the product as white solids $(2.07 \mathrm{~g}, 85 \%)$ : mp 181-183 $328{ }^{\circ} \mathrm{C}$ (lit. $\left.{ }^{20} 183-184{ }^{\circ} \mathrm{C}\right) ;{ }^{1} \mathrm{H}$ NMR $\left(400 \mathrm{MHz}, \mathrm{DMSO}-d_{6}\right) \delta 7.87$ (d, $J$ $329=8.0 \mathrm{~Hz}, 2 \mathrm{H}), 7.31(\mathrm{~d}, J=8.1 \mathrm{~Hz}, 2 \mathrm{H}), 7.21(\mathrm{~s}, 2 \mathrm{H}), 2.60(\mathrm{~s}, 6 \mathrm{H})$, $3302.33(\mathrm{~s}, 3 \mathrm{H}), 2.29(\mathrm{~s}, 3 \mathrm{H}) ;{ }^{13} \mathrm{C}\left\{{ }^{1} \mathrm{H}\right\}$ NMR (101 MHz, DMSO $) \delta$ 331 143.0, 142.2, 141.4, 134.5, 132.5, 129.7, 122.7, 110.9, 26.3, 20.8, 20.5 . 332 (4-Acetamidophenyl)(mesityl)iodonium Trifluoromethanesulfo333 nate (3h). GP1 was used on a $5 \mathrm{mmol}$ scale. Purification by 334 recrystallization in diethyl ether afforded the product as off-white 335 solids ( $741 \mathrm{mg}, 28 \%$ ): $\mathrm{mp} 136-138{ }^{\circ} \mathrm{C} ;{ }^{1} \mathrm{H}$ NMR (399 MHz, DMSO$\left.336 d_{6}\right) \delta 10.28(\mathrm{~s}, 1 \mathrm{H}), 7.93(\mathrm{~d}, J=8.7 \mathrm{~Hz}, 2 \mathrm{H}), 7.66(\mathrm{~d}, J=8.6 \mathrm{~Hz}, 2 \mathrm{H})$, $3377.20(\mathrm{~s}, 2 \mathrm{H}), 2.60(\mathrm{~s}, 6 \mathrm{H}), 2.28(\mathrm{~s}, 3 \mathrm{H}), 2.05(\mathrm{~s}, 3 \mathrm{H}) ;{ }^{13} \mathrm{C}\left\{{ }^{1} \mathrm{H}\right\} \mathrm{NMR}$ $338(100 \mathrm{MHz}, \mathrm{DMSO}) \delta 169.5,143.4,142.8,141.8,136.3,130.2,123.4$, $339122.7,122.0,106.3,26.7,24.6,21.0$; HRMS (ESI) calcd for $340 \mathrm{C}_{17} \mathrm{H}_{19} \mathrm{~F}_{3} \mathrm{INO}[\mathrm{M}-\mathrm{OTf}]^{+} 380.0506$, found 380.0514 .

341 (4-Fluorophenyl)(mesityl)iodonium Trifluoromethanesulfonate 342 (3i). ${ }^{20} \mathrm{GP} 1$ was used on a $5 \mathrm{mmol}$ scale. Purification by 343 recrystallization in diethyl ether afforded the product as gray solids 344 (1.96 g, 80\%): mp $173-176{ }^{\circ} \mathrm{C}$ (lit. $\left.{ }^{20} 177-178{ }^{\circ} \mathrm{C}\right) ;{ }^{1} \mathrm{H}$ NMR $(400$ $\left.345 \mathrm{MHz}, \mathrm{CDCl}_{3}\right) \delta 7.73(\mathrm{dd}, J=8.5,4.7 \mathrm{~Hz}, 2 \mathrm{H}), 7.10(\mathrm{~d}, J=4.9 \mathrm{~Hz}$, $3464 \mathrm{H}), 2.63$ (s, 6H), 2.35 (s, 3H); ${ }^{13} \mathrm{C}\left\{{ }^{1} \mathrm{H}\right\}$ NMR (101 MHz, $\mathrm{CDCl}_{3} \delta$ $347164.7(\mathrm{~d}, J=255.0 \mathrm{~Hz}), 144.6,142.5,135.7(\mathrm{~d}, J=8.7 \mathrm{~Hz}), 130.5$, $348121.2,120.3(\mathrm{q}, J=319.8 \mathrm{~Hz}), 119.8(\mathrm{~d}, J=22.9 \mathrm{~Hz}), 105.3(\mathrm{~d}, J=3.4$ $349 \mathrm{~Hz}), 27.2,21.3 ;{ }^{19} \mathrm{~F}$ NMR (376 MHz, $\left.\mathrm{CDCl}_{3}\right) \delta-78.40,-106.01$ 350 (ddd, $J=12.8,8.2,4.7 \mathrm{~Hz}$ ).

351 (4-lodophenyl)(mesityl)iodonium Trifluoromethanesulfonate 352 (3j). GP1 was used on a $5 \mathrm{mmol}$ scale. Purification by recrystallization 353 in diethyl ether afforded the product as dark white solids $(2.24 \mathrm{~g}$, $35475 \%)$ : mp $193-195{ }^{\circ} \mathrm{C} ;{ }^{1} \mathrm{H}$ NMR (400 MHz, DMSO- $\left.d_{6}\right) \delta 7.86(\mathrm{~d}, J$ $355=8.5 \mathrm{~Hz}, 2 \mathrm{H}), 7.71(\mathrm{~d}, J=8.5 \mathrm{~Hz}, 2 \mathrm{H}), 7.23(\mathrm{~s}, 2 \mathrm{H}), 2.58(\mathrm{~s}, 6 \mathrm{H})$, $3562.30(\mathrm{~s}, 3 \mathrm{H}) ;{ }^{13} \mathrm{C}\left\{{ }^{1} \mathrm{H}\right\}$ NMR $\left(101 \mathrm{MHz}, \mathrm{DMSO}-d_{6}\right) \delta 143.5,141.7$, $357141.6,140.4,136.8,136.0,129.9,129.82,122.7,122.6,116.3$ (q, $J=$ $358397.4 \mathrm{~Hz}), 99.7,26.3,20.5$.

$359 \quad\left[1,1^{\prime}\right.$-Biphenyl]-4-yl(mesityl)iodonium Trifluoromethanesulfonate 360 (3k). GP1 was used on a $5 \mathrm{mmol}$ scale. Purification by recrystallization 361 in diethyl ether afforded the product as pale green solids $(1.67 \mathrm{~g}$, $36261 \%$ ): $\mathrm{mp} 185-187{ }^{\circ} \mathrm{C}$; ${ }^{1} \mathrm{H}$ NMR $\left(400 \mathrm{MHz}, \mathrm{CDCl}_{3}\right) \delta 7.75(\mathrm{~d}, J=$ $3638.6 \mathrm{~Hz}, 2 \mathrm{H}), 7.63-7.58(\mathrm{~m}, 2 \mathrm{H}), 7.54-7.39(\mathrm{~m}, 5 \mathrm{H}), 7.14(\mathrm{~s}, 2 \mathrm{H})$, $3642.67(\mathrm{~s}, 6 \mathrm{H}), 2.38(\mathrm{~s}, 3 \mathrm{H}) ;{ }^{13} \mathrm{C}\left\{{ }^{1} \mathrm{H}\right\} \mathrm{NMR}\left(100 \mathrm{MHz}, \mathrm{CDCl}_{3}\right) \delta 145.4$, $365144.9,142.7,138.5,133.5,131.1,130.7,129.3,129.0,127.3,120.5$, 366 109.9, 27.4, 21.3; HRMS (ESI) calcd for $\mathrm{C}_{21} \mathrm{H}_{20} \mathrm{I}[\mathrm{M}-\mathrm{OTf}]^{+}$ 367399.0604 , found 399.0585 .

368 Mesityl(o-tolyl)iodonium Trifluoromethanesulfonate (3l). ${ }^{20}$ GP1 369 was used on a $5 \mathrm{mmol}$ scale. Purification by recrystallization in diethyl 370 ether afforded the product as white solids $(2.09 \mathrm{~g}, 86 \%)$ : mp 170-172
${ }^{\circ} \mathrm{C}\left(\right.$ lit. $\left.^{20} 167-168{ }^{\circ} \mathrm{C}\right) ;{ }^{1} \mathrm{H}$ NMR $\left(400 \mathrm{MHz}, \mathrm{CDCl}_{3}\right) \delta 7.50-7.38371$ $(\mathrm{m}, 3 \mathrm{H}), 7.17(\mathrm{td}, J=7.7,7.1,2.0 \mathrm{~Hz}, 1 \mathrm{H}), 7.11(\mathrm{~s}, 2 \mathrm{H}), 2.60(\mathrm{~s}, 9 \mathrm{H}), 372$ $2.36(\mathrm{~s}, 3 \mathrm{H}) ;{ }^{13} \mathrm{C}\left\{{ }^{1} \mathrm{H}\right\} \mathrm{NMR}\left(101 \mathrm{MHz}, \mathrm{CDCl}_{3}\right) \delta 144.8,142.7,140.4,373$ 133.7, 132.7, 132.6, 130.9, 130.0, 120.5 (q, $J=321.8 \mathrm{~Hz}), 119.7,115.8,374$ 27.1, 25.05, 21.2.

(2-Fluorophenyl)(mesityl)iodonium Trifluoromethanesulfonate 376 $(3 \mathrm{~m}){ }^{21}$ GP1 was used on a $5 \mathrm{mmol}$ scale. Purification by 377 recrystallization in diethyl ether afforded the product as white solids 378 (907 mg, 37\%): mp $\left.157-159{ }^{\circ} \mathrm{C} \mathrm{(lit.}{ }^{21} 161-162{ }^{\circ} \mathrm{C}\right) ;{ }^{1} \mathrm{H}$ NMR (399 379 $\left.\mathrm{MHz}, \mathrm{CDCl}_{3}\right) \delta 7.81$ (ddd, $J=7.8,5.8,1.6 \mathrm{~Hz}, 1 \mathrm{H}$ ), 7.59 (dddd, $J=380$ 8.6, 7.2, 5.4, $1.6 \mathrm{~Hz}, 1 \mathrm{H}), 7.35-7.19(\mathrm{~m}, 2 \mathrm{H}), 7.08(\mathrm{~s}, 2 \mathrm{H}), 2.68$ (s, 381 $6 \mathrm{H}), 2.34(\mathrm{~s}, 3 \mathrm{H}) ;{ }^{13} \mathrm{C}\left\{{ }^{1} \mathrm{H}\right\} \mathrm{NMR}\left(100 \mathrm{MHz}, \mathrm{CDCl}_{3}\right) \delta 160.5(\mathrm{~d}, J=382$ $252.1 \mathrm{~Hz}), 144.6,142.7,136.1,135.2(\mathrm{~d}, J=8.0 \mathrm{~Hz}), 130.6,127.6(\mathrm{~d}, J 383$ $=3.3 \mathrm{~Hz}), 121.5,117.6(\mathrm{~d}, J=21.8 \mathrm{~Hz}), 98.0(\mathrm{~d}, J=23.9 \mathrm{~Hz}), 27.1,384$ 21.2; ${ }^{19} \mathrm{~F}$ NMR ( $\left.376 \mathrm{MHz}, \mathrm{CDCl}_{3}\right) \delta-78.35,-95.37$ to $-96.24(\mathrm{~m}) .385$

Mesityl(m-tolyl)iodonium Trifluoromethanesulfonate (3n). ${ }^{21}$ GP1 386 was used on a $5 \mathrm{mmol}$ scale. Purification by recrystallization in diethyl 387 ether afforded the product as off-white solids (1.94 g, 80\%): mp 169- 388 $171{ }^{\circ} \mathrm{C}\left(\right.$ lit. $\left.^{21} 171-172{ }^{\circ} \mathrm{C}\right) ;{ }^{1} \mathrm{H}$ NMR $\left(399 \mathrm{MHz}, \mathrm{CDCl}_{3}\right) \delta 7.58$ (s, 389 $1 \mathrm{H}), 7.39$ (d, $J=7.9 \mathrm{~Hz}, 1 \mathrm{H}), 7.33(\mathrm{~d}, J=7.5 \mathrm{~Hz}, 1 \mathrm{H}), 7.26(\mathrm{t}, J=7.8390$ $\mathrm{Hz}, 1 \mathrm{H}), 7.10(\mathrm{~s}, 2 \mathrm{H}), 2.62(\mathrm{~s}, 6 \mathrm{H}), 2.35(\mathrm{~s}, 6 \mathrm{H}) ;{ }^{13} \mathrm{C}\left\{{ }^{1} \mathrm{H}\right\}$ NMR $(100391$ $\left.\mathrm{MHz}, \mathrm{CDCl}_{3}\right) \delta 144.6,143.3,142.7,133.6,132.9,132.1,130.5,129.9,392$ $120.5(\mathrm{q}, J=320.5 \mathrm{~Hz}), 120.2,111.6,27.3,21.5,21.3$.

(3,5-Dimethylphenyl)(mesityl)iodonium Trifluoromethanesulfo- 394 nate (30). GP1 was used on a $5 \mathrm{mmol}$ scale. Purification by 395 recrystallization in diethyl ether afforded the product as off-white 396 solids (1.80 g, 72\%): mp 200-203 ${ }^{\circ} \mathrm{C} ;{ }^{1} \mathrm{H}$ NMR $\left(399 \mathrm{MHz}, \mathrm{CDCl}_{3}\right) \delta 397$ $7.28(\mathrm{~s}, 2 \mathrm{H}), 7.14(\mathrm{~s}, 1 \mathrm{H}), 7.11(\mathrm{~s}, 2 \mathrm{H}), 2.63(\mathrm{~s}, 6 \mathrm{H}), 2.36(\mathrm{~s}, 3 \mathrm{H}), 398$ $2.30(\mathrm{~s}, 6 \mathrm{H}) ;{ }^{13} \mathrm{C}\left\{{ }^{1} \mathrm{H}\right\} \mathrm{NMR}\left(100 \mathrm{MHz}, \mathrm{CDCl}_{3}\right) \delta 144.6,142.9,142.7,399$ 134.0, 130.6, 130.5, 120.7 (q, $J=321.3 \mathrm{~Hz}), 120.0,111.4,27.3,21.5,400$ 21.3; HRMS (ESI) calcd for $\mathrm{C}_{17} \mathrm{H}_{20} \mathrm{I}[\mathrm{M}-\mathrm{OTf}]^{+} 351.0604$, found 401 351.0616.

Dimesityliodonium Trifluoromethanesulfonate (3p). ${ }^{19}$ GP1 was 403 used on a $5 \mathrm{mmol}$ scale. Purification by recrystallization in diethyl 404 ether afforded the product as brown solids (1.44 g, 56\%). GP3 was 405 used on a $4 \mathrm{mmol}$ scale. Purification by recrystallization in diethyl 406 ether afforded the product as brown solids (1.08 g, 53\%): $\mathrm{mp} 183-407$ $186{ }^{\circ} \mathrm{C}$ (lit. $\left.{ }^{19} 187-188{ }^{\circ} \mathrm{C}\right) ;{ }^{1} \mathrm{H}$ NMR $\left(400 \mathrm{MHz}, \mathrm{CDCl}_{3}\right) \delta 7.05$ (s, 408 $4 \mathrm{H}), 2.51(\mathrm{~s}, 12 \mathrm{H}), 2.33(\mathrm{~s}, 6 \mathrm{H}) ;{ }^{13} \mathrm{C}\left\{{ }^{1} \mathrm{H}\right\} \operatorname{NMR}\left(101 \mathrm{MHz}, \mathrm{CDCl}_{3}\right) \delta 409$ 144.0, 142.4, 131.1, 117.4, 26.3, 21.1.

Mesityl(4-methoxyphenyl)iodonium Trifluoromethanesulfonate 411 $(3 q)^{2 c}$ GP1 was used on a $5 \mathrm{mmol}$ scale. Purification by 412 recrystallization in diethyl ether afforded the product as dark gray 413 solids (502 mg, 20\%): mp 148-150 ${ }^{\circ} \mathrm{C}$ (lit. $\left.{ }^{2 \mathrm{C}} 148-151{ }^{\circ} \mathrm{C}\right) ;{ }^{1} \mathrm{H}$ NMR 414 $\left(400 \mathrm{MHz}, \mathrm{CDCl}_{3}\right) \delta$ 7.69-7.57 (m, 2H), $7.10(\mathrm{~s}, 2 \mathrm{H}), 6.98-6.85(\mathrm{~m}, 415$ $2 \mathrm{H}), 3.82(\mathrm{~s}, 3 \mathrm{H}), 2.64(\mathrm{~s}, 6 \mathrm{H}), 2.35(\mathrm{~s}, 3 \mathrm{H}) ;{ }^{13} \mathrm{C}\left\{{ }^{1} \mathrm{H}\right\}$ NMR $(101416$ $\left.\mathrm{MHz}, \mathrm{CDCl}_{3}\right) \delta 162.8,144.7,142.4,135.5,130.6,121.0,118.3,99.9,417$ 55.9, 27.2, 21.3

418

Mesityl(thiophen-2-yl)iodonium Trifluoromethanesulfonate (3r). 419 GP1 was used on a $5 \mathrm{mmol}$ scale. Purification by recrystallization in 420 diethyl ether afforded the product as light brown solids (1.20 g, 50\%): 421 mp $160-162{ }^{\circ} \mathrm{C} ;{ }^{1} \mathrm{H}$ NMR $\left(400 \mathrm{MHz}, \mathrm{CDCl}_{3}\right) \delta 7.73$ (dd, $J=3.8,1.2422$ $\mathrm{Hz}, 1 \mathrm{H}), 7.61(\mathrm{dd}, J=5.4,1.2 \mathrm{~Hz}, 1 \mathrm{H}), 7.11-7.04(\mathrm{~m}, 3 \mathrm{H}), 2.73(\mathrm{~s}, 423$ $6 \mathrm{H}), 2.33(\mathrm{~s}, 3 \mathrm{H}) ;{ }^{13} \mathrm{C}\left\{{ }^{1} \mathrm{H}\right\} \mathrm{NMR}\left(101 \mathrm{MHz}, \mathrm{CDCl}_{3}\right) \delta 144.5,141.7,424$ 139.7, 135.8, 130.6, 129.8, 125.7, $120.3(\mathrm{q}, J=319.6 \mathrm{~Hz}), 94.5,27.2,425$ 21.2; HRMS (ESI) calcd for $\mathrm{C}_{13} \mathrm{H}_{14} \mathrm{IS}[\mathrm{M}-\mathrm{OTf}]^{+} 328.9855$, found 426 328.9857.

(9,10-Dioxo-9,10-dihydroanthracen-1-yl)(p-tolyl)iodonium Tri- 428 fluoromethanesulfonate (3s). GP2 was used on a $5 \mathrm{mmol}$ scale. 429 Purification by recrystallization in diethyl ether afforded the product as 430 light gray solids (1.29 g, 45\%): $\mathrm{mp} 225-230{ }^{\circ} \mathrm{C} ;{ }^{1} \mathrm{H}$ NMR (400 MHz, 431 DMSO- $\left.d_{6}\right) \delta 8.47-8.41(\mathrm{~m}, 1 \mathrm{H}), 8.39(\mathrm{dd}, J=7.0,2.0 \mathrm{~Hz}, 1 \mathrm{H}), 8.30432$ $(\mathrm{dd}, J=7.2,1.9 \mathrm{~Hz}, 1 \mathrm{H}), 8.25(\mathrm{~d}, J=8.3 \mathrm{~Hz}, 2 \mathrm{H}), 8.09(\mathrm{qd}, J=7.3,433$ $1.7 \mathrm{~Hz}, 2 \mathrm{H}), 8.02(\mathrm{t}, J=8.0 \mathrm{~Hz}, 1 \mathrm{H}), 7.59(\mathrm{~d}, J=8.4 \mathrm{~Hz}, 2 \mathrm{H}), 7.36434$ $(\mathrm{dd}, J=8.2,1.0 \mathrm{~Hz}, 1 \mathrm{H}), 2.52(\mathrm{~s}, 3 \mathrm{H}) ;{ }^{13} \mathrm{C}\left\{{ }^{1} \mathrm{H}\right\} \mathrm{NMR}(101 \mathrm{MHz}, 435$ DMSO) $\delta 185.3,181.2,144.9,138.1,137.3,136.9,136.3,135.7,133.7,436$ $133.3,132.2,131.9,130.4,129.9,128.2,127.8,114.7,108.4,21.7$; 437 HRMS (ESI) calcd for $\mathrm{C}_{21} \mathrm{H}_{14} \mathrm{IO}_{2}[\mathrm{M}-\mathrm{OTf}]^{+}$425.0033, found 438 425.0030 . 
440 Bis(4-chlorophenyl)iodonium Trifluoromethanesulfonate (3t). ${ }^{2 c}$ 441 GP2 was used on a $5 \mathrm{mmol}$ scale. Purification by recrystallization in 442 diethyl ether afforded the product as white solids ( $1.57 \mathrm{~g}, 63 \%)$. GP3 443 was used on a $4 \mathrm{mmol}$ scale. Purification by recrystallization in diethyl 444 ether afforded the product as white solids (1.32 g, 66\%): mp 183-187 $445{ }^{\circ} \mathrm{C}$ (lit. $\left.{ }^{2 \mathrm{C}} 185-186{ }^{\circ} \mathrm{C}\right) ;{ }^{1} \mathrm{H}$ NMR $\left(400 \mathrm{MHz}\right.$, DMSO- $\left.d_{6}\right) \delta 8.42-8.08$ $446(\mathrm{~m}, 4 \mathrm{H}), 7.75-7.47(\mathrm{~m}, 4 \mathrm{H}) ;{ }^{13} \mathrm{C}\left\{{ }^{1} \mathrm{H}\right\}$ NMR (101 MHz, DMSO) $\delta$ 447 137.9, 137.4, 132.3, 115.2.

448 Bis(4-bromophenyl)iodonium Trifluoromethanesulfonate (3u). ${ }^{2 c}$ 449 GP2 was used on a $5 \mathrm{mmol}$ scale. Purification by recrystallization in 450 diethyl ether afforded the product as white solids ( $2.37 \mathrm{~g}, 81 \%)$. GP3 451 was used on a $4 \mathrm{mmol}$ scale. Purification by recrystallization in diethyl 452 ether afforded the product as white solids (1.46 g, 62\%): $\mathrm{mp} 183-188$ $453{ }^{\circ} \mathrm{C}\left(\right.$ lit. $\left.^{2 \mathrm{c}} 185-190{ }^{\circ} \mathrm{C}\right) ;{ }^{1} \mathrm{H}$ NMR (400 MHz, DMSO- $\left.d_{6}\right) \delta 8.17$ (d, $J$ $454=8.6 \mathrm{~Hz}, 4 \mathrm{H}), 7.77(\mathrm{~d}, J=8.6 \mathrm{~Hz}, 4 \mathrm{H}) ;{ }^{13} \mathrm{C}\left\{{ }^{1} \mathrm{H}\right\} \mathrm{NMR}(101 \mathrm{MHz}$, 455 DMSO-d $\left.d_{6}\right) \delta 137.0,134.7,126.3,115.4$.

456 (4-Bromophenyl)(4-chlorophenyl)iodonium Trifluoromethane457 sulfonate (3v). GP2 was used on a $5 \mathrm{mmol}$ scale. Purification by 458 recrystallization in diethyl ether afforded the product as white needles 459 (2.01g, 74\%): mp 201-204 ${ }^{\circ} \mathrm{C}$; ${ }^{1} \mathrm{H}$ NMR (399 MHz, DMSO- $\left.d_{6}\right) \delta$ $4608.31-8.23(\mathrm{~m}, 2 \mathrm{H}), 8.26-8.13(\mathrm{~m}, 2 \mathrm{H}), 7.86-7.71(\mathrm{~m}, 2 \mathrm{H}), 7.70-$ $4617.58(\mathrm{~m}, 2 \mathrm{H}) ;{ }^{13} \mathrm{C}\left\{{ }^{1} \mathrm{H}\right\}$ NMR (100 MHz, DMSO- $\left.d_{6}\right) \delta$ 138.0, 137.5, $462137.5,135.2,132.3,126.8,121.2(\mathrm{q}, J=322.5 \mathrm{~Hz}), 115.9,115.1$; 463 HRMS (ESI) calcd for $\mathrm{C}_{12} \mathrm{H}_{8} \mathrm{BrClI}[\mathrm{M}-\mathrm{OTf}]^{+} 392.8537$, found 464392.8553.

465 (4-Nitrophenyl)(phenyl)iodonium Trifluoromethanesulfonate $466(3 w){ }^{2 c}$ GP2 was used on a $5 \mathrm{mmol}$ scale. Purification by 467 recrystallization in diethyl ether afforded the product as yellow solids 468 (1.76 g, 74\%): mp $178-183{ }^{\circ} \mathrm{C}$ (lit. $\left.{ }^{2 \mathrm{c}} 180-185{ }^{\circ} \mathrm{C}\right) ;{ }^{1} \mathrm{H}$ NMR $(400$ $\left.469 \mathrm{MHz}, \mathrm{DMSO}-d_{6}\right) \delta 8.51-8.45(\mathrm{~m}, 2 \mathrm{H}), 8.35-8.27(\mathrm{~m}, 4 \mathrm{H}), 7.74-$ $4707.65(\mathrm{~m}, 1 \mathrm{H}), 7.61-7.50(\mathrm{~m}, 2 \mathrm{H}) ;{ }^{13} \mathrm{C}\left\{{ }^{1} \mathrm{H}\right\}$ NMR (101 MHz, DMSO$\left.471 d_{6}\right) \delta 149.4,136.4,135.5,132.4,131.96,126.3,122.6,120.7(\mathrm{q}, J=$ $472322.4 \mathrm{~Hz}), 116.9$.

473 Mono(3-(p-tolyliodonio)pyridin-1-ium) Bis474 (trifluoromethanesulfonate) $(3 x) .^{2 c}$ GP2 was used on a $5 \mathrm{mmol}$ 475 scale. Purification by recrystallization in diethyl ether afforded the 476 product as light yellow solids $(1.40 \mathrm{~g}, 47 \%)$ : mp $163-167{ }^{\circ} \mathrm{C}$ (lit. $^{2 \mathrm{C}}$ $\left.477170-172{ }^{\circ} \mathrm{C}\right) ;{ }^{1} \mathrm{H}$ NMR $\left(400 \mathrm{MHz}, \mathrm{DMSO}-d_{6}\right) \delta 9.27(\mathrm{~d}, J=2.2 \mathrm{~Hz}$, $4781 \mathrm{H}), 8.82(\mathrm{dd}, J=4.7,1.4 \mathrm{~Hz}, 1 \mathrm{H}), 8.64(\mathrm{dt}, J=8.2,1.8 \mathrm{~Hz}, 1 \mathrm{H})$, $4798.26-8.07(\mathrm{~m}, 2 \mathrm{H}), 7.58(\mathrm{dd}, J=8.2,4.7 \mathrm{~Hz}, 1 \mathrm{H}), 7.36(\mathrm{~d}, J=8.1 \mathrm{~Hz}$, $4802 \mathrm{H}), 2.35$ (s, 3H); ${ }^{13} \mathrm{C}\left\{{ }^{1} \mathrm{H}\right\}$ NMR (101 MHz, DMSO-d 6 ) $\delta$ 153.4, $481152.1,142.9,142.3,135.3,132.5,126.9,120.7$ (q, $J=323.3 \mathrm{~Hz}), 116.2$, 482 113.0, 20.9.

483 Mesityl(4-(trifluoromethyl)phenyl)iodonium Trifluoromethane484 sulfonate (3y). GP2 was used on a $5 \mathrm{mmol}$ scale. Purification by 485 recrystallization in diethyl ether afforded the product as brown solids

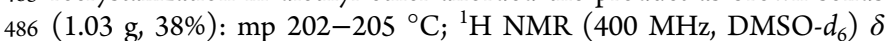
4878.14 (d, $J=8.3 \mathrm{~Hz}, 2 \mathrm{H}), 7.87(\mathrm{~d}, J=8.4 \mathrm{~Hz}, 2 \mathrm{H}), 7.25(\mathrm{~s}, 2 \mathrm{H}), 2.59$ 488 (s, 6H), $2.31(\mathrm{~s}, 3 \mathrm{H}) ;{ }^{13} \mathrm{C}\left\{{ }^{1} \mathrm{H}\right\}$ NMR (101 MHz, DMSO-d $\left.d_{6}\right) \delta 143.5$, $489141.74,135.0,131.8,129.9,128.4(\mathrm{~d}, J=3.7 \mathrm{~Hz}), 124.7,122.6,120.5$ $490(\mathrm{q}, J=295.3 \mathrm{~Hz}), 118.7,26.3,20.5 ;{ }^{19} \mathrm{~F}$ NMR $\left(376 \mathrm{MHz}\right.$, DMSO- $\left.d_{6}\right)$ $491 \delta-61.68,-77.75$; HRMS (ESI) calcd for $\mathrm{C}_{16} \mathrm{H}_{15} \mathrm{~F}_{3} \mathrm{I}[\mathrm{M}-\mathrm{OTf}]^{+}$ 492391.0165 , found 391.0183 .

493 (4-Chlorophenyl)(mesityl)iodonium Trifluoromethanesulfonate $494(3 z){ }^{20}$ GP2 was used on a $5 \mathrm{mmol}$ scale. Purification by 495 recrystallization in diethyl ether afforded the product as light gray 496 solids $(2.21 \mathrm{~g}, 87 \%)$ : $\mathrm{mp} 161-163{ }^{\circ} \mathrm{C}$ (lit. $\left.{ }^{20} 132-133{ }^{\circ} \mathrm{C}\right) ;{ }^{1} \mathrm{H}$ NMR $497\left(400 \mathrm{MHz}, \mathrm{CDCl}_{3}\right) \delta 7.67-7.60(\mathrm{~m}, 2 \mathrm{H}), 7.40-7.34(\mathrm{~m}, 2 \mathrm{H}), 7.11(\mathrm{~s}$, $4982 \mathrm{H}), 2.62(\mathrm{~s}, 6 \mathrm{H}), 2.36(\mathrm{~s}, 3 \mathrm{H}) ;{ }^{13} \mathrm{C}\left\{{ }^{1} \mathrm{H}\right\} \mathrm{NMR}\left(101 \mathrm{MHz}, \mathrm{CDCl}_{3}\right) \delta$ $499144.8,142.6,138.9,134.4,132.5,130.6,120.9,120.8(\mathrm{q}, J=237.7 \mathrm{~Hz})$, $500108.9,27.2,21.3$.

501 (4-Bromophenyl)(mesityl)iodonium Trifluoromethanesulfonate $502(3 a a){ }^{20}$ GP2 was used on a $5 \mathrm{mmol}$ scale. Purification by 503 recrystallization in diethyl ether afforded the product as light gray 504 solids $(2.48 \mathrm{~g}, 90 \%)$ : $\mathrm{mp} 187-190{ }^{\circ} \mathrm{C}$ (lit. $\left.{ }^{20} 179-180{ }^{\circ} \mathrm{C}\right) ;{ }^{1} \mathrm{H}$ NMR $505\left(400 \mathrm{MHz}, \mathrm{CDCl}_{3}\right) \delta 7.57(\mathrm{~d}, J=8.8 \mathrm{~Hz}, 2 \mathrm{H}), 7.50(\mathrm{~d}, J=8.8 \mathrm{~Hz}$, $5062 \mathrm{H}), 7.09$ (s, 2H), $2.61(\mathrm{~s}, 6 \mathrm{H}), 2.34(\mathrm{~s}, 3 \mathrm{H}) ;{ }^{13} \mathrm{C}\left\{{ }^{1} \mathrm{H}\right\}$ NMR $(101$ $\left.507 \mathrm{MHz} \mathrm{CDCl}_{3}\right) \delta 144.6,142.6,135.3,134.7,130.5,126.9,120.9,120.3$ $508(\mathrm{q}, J=319.9 \mathrm{~Hz}), 109.9,27.2,21.3$.
(4-(Ethoxycarbonyl)phenyl)(mesityl)iodonium Triflate $(3 a b) .{ }^{20} 509$ GP2 was used on a $5 \mathrm{mmol}$ scale. Purification by recrystallization in 510 diethyl ether afforded the product as gray solids (1.39 g, 51\%): $\mathrm{mp} 511$ $173-175^{\circ} \mathrm{C}$ (lit. $\left.{ }^{20} 178-179{ }^{\circ} \mathrm{C}\right) ;{ }^{1} \mathrm{H}$ NMR $\left(399 \mathrm{MHz}, \mathrm{CDCl}_{3}\right) \delta 8.01512$ $(\mathrm{d}, J=8.6 \mathrm{~Hz}, 2 \mathrm{H}), 7.76(\mathrm{~d}, J=8.7 \mathrm{~Hz}, 2 \mathrm{H}), 7.11(\mathrm{~d}, J=1.0 \mathrm{~Hz}, 2 \mathrm{H}), 513$ $4.36(\mathrm{q}, J=7.1 \mathrm{~Hz}, 2 \mathrm{H}), 2.61(\mathrm{~s}, 6 \mathrm{H}), 2.36(\mathrm{~s}, 3 \mathrm{H}), 1.36(\mathrm{t}, J=7.1 \mathrm{~Hz}, 514$ $3 \mathrm{H}) ;{ }^{13} \mathrm{C}\left\{{ }^{1} \mathrm{H}\right\} \mathrm{NMR}\left(100 \mathrm{MHz}, \mathrm{CDCl}_{3}\right) \delta 164.9,144.8,142.7,133.7,515$ $132.9,132.8,130.5,120.7,120.3(\mathrm{q}, J=319.9 \mathrm{~Hz}), 116.5,62.0,27.2,516$ 21.3, 14.3 .

(4-Acetylphenyl)(mesityl)iodonium Trifluoromethanesulfonate 518 (3ac). ${ }^{21}$ GP2 was used on a $5 \mathrm{mmol}$ scale. Purification by 519 recrystallization in diethyl ether afforded the product as gray solids 520 (2.03 g. $79 \%$ ): mp $183-184{ }^{\circ} \mathrm{C}\left(\right.$ lit. $\left.^{21} 183-185{ }^{\circ} \mathrm{C}\right) ;{ }^{1} \mathrm{H}$ NMR $(399521$ $\left.\mathrm{MHz}, \mathrm{CDCl}_{3}\right) \delta 7.94(\mathrm{~d}, J=8.7 \mathrm{~Hz}, 2 \mathrm{H}), 7.79(\mathrm{~d}, J=8.7 \mathrm{~Hz}, 2 \mathrm{H}), 522$ $7.14(\mathrm{~s}, 2 \mathrm{H}), 2.62(\mathrm{~s}, 6 \mathrm{H}), 2.59(\mathrm{~s}, 3 \mathrm{H}), 2.38(\mathrm{~s}, 3 \mathrm{H}) ;{ }^{13} \mathrm{C}\left\{{ }^{1} \mathrm{H}\right\}$ NMR 523 $\left(100 \mathrm{MHz}, \mathrm{CDCl}_{3}\right) \delta 196.3,145.1,142.8,139.6,133.0,131.6,130.7,524$ 120.4, 116.6, 27.3, 26.8, 21.3.

Mesityl(3-(trifluoromethyl)phenyl)iodonium Trifluoromethane- 526 sulfonate (3ad). ${ }^{20}$ GP2 was used on a $5 \mathrm{mmol}$ scale. Purification by 527 recrystallization in diethyl ether to afford the product as brown solids 528 (1.24 g, 46\%): mp $180-182{ }^{\circ} \mathrm{C}$ (lit. $\left.{ }^{20} 181-183{ }^{\circ} \mathrm{C}\right) ;{ }^{1} \mathrm{H}$ NMR (400 529 $\left.\mathrm{MHz}^{\mathrm{CDCl}}{ }_{3}\right) \delta 7.94(\mathrm{~d}, J=8.4 \mathrm{~Hz}, 1 \mathrm{H}), 7.91(\mathrm{~s}, 1 \mathrm{H}), 7.77(\mathrm{~d}, J=7.8530$ $\mathrm{Hz}, 1 \mathrm{H}), 7.54(\mathrm{t}, J=8.0 \mathrm{~Hz}, 1 \mathrm{H}), 7.12(\mathrm{~s}, 2 \mathrm{H}), 2.63(\mathrm{~s}, 6 \mathrm{H}), 2.36(\mathrm{~s}, 531$ $3 \mathrm{H}) ;{ }^{13} \mathrm{C}\left\{{ }^{1} \mathrm{H}\right\}$ NMR $\left(101 \mathrm{MHz}, \mathrm{CDCl}_{3}\right) \delta 144.9,142.7,134.2(\mathrm{~d}, J=532$ $33.8 \mathrm{~Hz}), 132.5,130.6,129.8(\mathrm{~d}, J=4.0 \mathrm{~Hz}), 128.6(\mathrm{~d}, J=3.7 \mathrm{~Hz}), 533$ $123.9,121.2,121.0,120.2(\mathrm{q}, J=319.2 \mathrm{~Hz}), 112.1,27.221 .3 ;{ }^{19} \mathrm{~F} 534$ NMR $\left(376 \mathrm{MHz}, \mathrm{CDCl}_{3}\right) \delta-63.05,-78.53$.

Mesityl(3-nitrophenyl)iodonium Trifluoromethanesulfonate 536 (3ae). GP2 was used on a $5 \mathrm{mmol}$ scale. Purification by 537 recrystallization in diethyl ether afforded the product as brown solids 538 (1.19 g, 46\%): mp $162-164{ }^{\circ} \mathrm{C} ;{ }^{1} \mathrm{H}$ NMR (400 MHz, DMSO- $\left.d_{6}\right) \delta 539$ $8.82(\mathrm{t}, J=2.0 \mathrm{~Hz}, 1 \mathrm{H}), 8.42(\mathrm{ddd}, J=8.2,2.2,0.9 \mathrm{~Hz}, 1 \mathrm{H}), 8.18(\mathrm{ddd}, 540$ $J=8.0,1.8,0.9 \mathrm{~Hz}, 1 \mathrm{H}), 7.75(\mathrm{t}, J=8.2 \mathrm{~Hz}, 1 \mathrm{H}), 7.26(\mathrm{~s}, 2 \mathrm{H}), 2.61(\mathrm{~s}, 541$ $6 \mathrm{H}), 2.32(\mathrm{~s}, 3 \mathrm{H}) ;{ }^{13} \mathrm{C}\left\{{ }^{1} \mathrm{H}\right\}$ NMR (101 MHz, DMSO- $\left.d_{6}\right) \delta 148.6,542$ $143.6,141.9,139.7,132.9,130.0,128.9,126.4,122.7,120.7$ (q, $J=543$ $322.1 \mathrm{~Hz}$ ), 114.1, 26.4, 20.6; HRMS (ESI) calcd for $\mathrm{C}_{15} \mathrm{H}_{15} \mathrm{INO}_{2}$ [M 544 - OTf] ${ }^{+} 368.0142$, found 368.0154 .

(2-Chlorophenyl)(mesityl)iodonium Trifluoromethanesulfonate 546 (3af). ${ }^{21}$ GP2 was used on a $5 \mathrm{mmol}$ scale. Purification by 547 recrystallization in diethyl ether afforded the product as brown solids 548 (1.24 g, 49\%): mp $171-172{ }^{\circ} \mathrm{C}$ (lit. $\left.{ }^{21} 167-168{ }^{\circ} \mathrm{C}\right) ;{ }^{1} \mathrm{H}$ NMR (399 549 $\left.\mathrm{MHz} \mathrm{CDCl}_{3}\right) \delta 7.62(\mathrm{dd}, J=8.0,1.5 \mathrm{~Hz}, 1 \mathrm{H}), 7.53(\mathrm{td}, J=7.7,1.4550$ $\mathrm{Hz}, 1 \mathrm{H}), 7.29$ (td, $J=7.8,7.4,1.5 \mathrm{~Hz}, 1 \mathrm{H}), 7.17(\mathrm{~s}, 2 \mathrm{H}), 7.09$ (dd, $J=551$ 8.2, $1.4 \mathrm{~Hz}, 1 \mathrm{H}), 2.62(\mathrm{~s}, 6 \mathrm{H}), 2.40(\mathrm{~s}, 3 \mathrm{H}) ;{ }^{13} \mathrm{C}\left\{{ }^{1} \mathrm{H}\right\}$ NMR $(100552$ $\left.\mathrm{MHz}, \mathrm{CDCl}_{3}\right) \delta 145.4,143.0,135.5,133.5,132.5,131.4,131.0,130.6,553$ $120.8,120.4(\mathrm{q}, J=319.9 \mathrm{~Hz}), 112.5,27.2,21.3$.

(2-Bromophenyl)(mesityl)iodonium Trifluoromethanesulfonate 555 (3ag). ${ }^{21}$ GP2 was used on a $5 \mathrm{mmol}$ scale. Purification by 556 recrystallization in diethyl ether afforded the product as brown solids 557 (1.54 g, 56\%): mp $172-173{ }^{\circ} \mathrm{C}$ (lit. $\left.{ }^{21} 167-168{ }^{\circ} \mathrm{C}\right) ;{ }^{1} \mathrm{H}$ NMR $(399558$ $\left.\mathrm{MHz} \mathrm{CDCl}_{3}\right) \delta 7.74(\mathrm{dd}, J=8.0,1.5 \mathrm{~Hz}, 1 \mathrm{H}), 7.46(\mathrm{td}, J=7.7,1.5559$ $\mathrm{Hz}, 1 \mathrm{H}), 7.33$ (ddd, $J=8.9,7.5,1.5 \mathrm{~Hz}, 1 \mathrm{H}), 7.20(\mathrm{~s}, 2 \mathrm{H}), 6.86$ (dd, $J 560$ $=8.2,1.4 \mathrm{~Hz}, 1 \mathrm{H}), 2.61(\mathrm{~s}, 6 \mathrm{H}), 2.41(\mathrm{~s}, 3 \mathrm{H}) ;{ }^{13} \mathrm{C}\left\{{ }^{1} \mathrm{H}\right\}$ NMR $(100561$ $\left.\mathrm{MHz} \mathrm{CDCl}_{3}\right) \delta 145.6,143.0,134.6,133.3,131.5,131.2,131.0,124.7,562$ 121.6, 120.4 (q, $J=319.8 \mathrm{~Hz}), 115.4,27.2,21.4$.

Mesityl(2-(trifluoromethyl)phenyl)iodonium Trifluoromethane- 564 sulfonate (3ah). ${ }^{21}$ GP2 was used on a $5 \mathrm{mmol}$ scale. Purification by 565 recrystallization in diethyl ether afforded the product as brown solids 566 (891 mg, 33\%): mp $176-178{ }^{\circ} \mathrm{C}\left(\right.$ lit. $\left.^{21} 180-181{ }^{\circ} \mathrm{C}\right) ;{ }^{1} \mathrm{H}$ NMR $(400567$ $\left.\mathrm{MHz}, \mathrm{CDCl}_{3}\right) \delta 7.96-7.89(\mathrm{~m}, 1 \mathrm{H}), 7.71(\mathrm{t}, J=7.6 \mathrm{~Hz}, 1 \mathrm{H}), 7.54(\mathrm{td}, 568$ $J=7.8,1.6 \mathrm{~Hz}, 1 \mathrm{H}), 7.28(\mathrm{~d}, J=8.0 \mathrm{~Hz}, 1 \mathrm{H}), 7.19(\mathrm{~s}, 2 \mathrm{H}), 2.62(\mathrm{~s}, 569$ $6 \mathrm{H}), 2.41(\mathrm{~s}, 3 \mathrm{H}) ;{ }^{13} \mathrm{C}\left\{{ }^{1} \mathrm{H}\right\}$ NMR $\left(101 \mathrm{MHz}, \mathrm{CDCl}_{3}\right) \delta 145.9,143.1,570$ 135.8, 133.1, 132.2, 131.4, 131.1, 129.6 (d, $J=4.8 \mathrm{~Hz}$ ), 124.1, 121.9, 571 $120.1(\mathrm{q}, J=264.9 \mathrm{~Hz}), 107.5,27.2,21.4 ;{ }^{19} \mathrm{~F}$ NMR $(376 \mathrm{MHz}, 572$ $\left.\mathrm{CDCl}_{3}\right) \delta-59.93,-78.44$.

3-(Mesityliodonio)pyridin-1-ium Bis(trifluoromethanesulfonate) 574 (3ai). ${ }^{2 C}$ GP2 was used on a $5 \mathrm{mmol}$ scale. Purification by 575 recrystallization in diethyl ether afforded the product as light yellow 576 solids (592 mg, 19\%): mp 155-158 ${ }^{\circ} \mathrm{C}\left(\right.$ lit. $\left.^{2 \mathrm{C}} 138-141{ }^{\circ} \mathrm{C}\right) ;{ }^{1} \mathrm{H}$ NMR 577 $\left(400 \mathrm{MHz}, \mathrm{DMSO}-d_{6}\right) \delta 9.06(\mathrm{~d}, J=2.3 \mathrm{~Hz}, 1 \mathrm{H}), 8.79(\mathrm{dd}, J=4.8,1.3578$ 
$579 \mathrm{~Hz}, 1 \mathrm{H}), 8.42(\mathrm{~d}, J=8.4 \mathrm{~Hz}, 1 \mathrm{H}), 7.55(\mathrm{dd}, J=8.3,4.7 \mathrm{~Hz}, 1 \mathrm{H}), 7.23$ $580(\mathrm{~s}, 2 \mathrm{H}), 2.61(\mathrm{~s}, 6 \mathrm{H}), 2.30(\mathrm{~s}, 3 \mathrm{H}) ;{ }^{13} \mathrm{C}\left\{{ }^{1} \mathrm{H}\right\}$ NMR $(101 \mathrm{MHz}$, 581 DMSO- $\left.d_{6}\right) \delta 152.9,151.9,143.3,142.1,141.6,129.9,127.1,122.6$, $582120.7(\mathrm{q}, J=322.4 \mathrm{~Hz}), 114.2,26.3,20.5$.

583 Mesityl(4-nitrophenyl)iodonium Trifluoromethanesulfonate 584 (3aj). ${ }^{20}$ GP2 was used on a 5 mmol scale. Purification by 585 recrystallization in diethyl ether afforded the product as brown solids 586 (827 mg, 32\%): mp $197-200{ }^{\circ} \mathrm{C}\left(\right.$ lit. $\left.^{20} 208^{\circ} \mathrm{C}\right) ;{ }^{1} \mathrm{H}$ NMR $(399 \mathrm{MHz}$, $\left.587 \mathrm{DMSO}_{-} \mathrm{d}_{6}\right) \delta 8.26(\mathrm{~d}, J=8.4 \mathrm{~Hz}, 2 \mathrm{H}), 8.22-8.12(\mathrm{~m}, 2 \mathrm{H}), 7.26(\mathrm{~s}$, $5882 \mathrm{H}), 2.59(\mathrm{~s}, 6 \mathrm{H}), 2.31(\mathrm{~s}, 3 \mathrm{H}) ;{ }^{13} \mathrm{C}\left\{{ }^{1} \mathrm{H}\right\}$ NMR (100 MHz, DMSO$\left.589 d_{6}\right) \delta 149.3,143.6,141.8,135.5,130.0,126.2,122.8(\mathrm{q}, J=201.9 \mathrm{~Hz})$, $59026.3,20.6$.

591 o-Tolyl(p-tolyl)iodonium Trifluoromethanesulfonate (3ak). ${ }^{11 b}$ 592 GP3 was used on a 4 mmol scale. Purification by recrystallization in 593 diethyl ether afforded the product as brown solids (ortho-para $90 \%$, 594 para-para $5 \%$, ortho-ortho $5 \%, 770 \mathrm{mg}$, 42\%): $\mathrm{mp} 158-160{ }^{\circ} \mathrm{C} ;{ }^{1} \mathrm{H}$ $595 \mathrm{NMR}\left(400 \mathrm{MHz}, \mathrm{CDCl}_{3}\right) \delta 8.09(\mathrm{dd}, J=8.1,1.2 \mathrm{~Hz}, 1 \mathrm{H}), 7.85-7.71$ $596(\mathrm{~m}, 2 \mathrm{H}), 7.52(\mathrm{td}, J=7.5,1.2 \mathrm{~Hz}, 1 \mathrm{H}), 7.43(\mathrm{dd}, J=7.7,1.7 \mathrm{~Hz}, 1 \mathrm{H})$, $5977.22(\mathrm{t}, J=5.4 \mathrm{~Hz}, 3 \mathrm{H}), 2.60(\mathrm{~s}, 3 \mathrm{H}), 2.37(\mathrm{~s}, 3 \mathrm{H}) ;{ }^{13} \mathrm{C}\left\{{ }^{1} \mathrm{H}\right\} \mathrm{NMR}$ $598\left(101 \mathrm{MHz}, \mathrm{CDCl}_{3}\right) \delta 143.4,141.4,137.6,134.7,133.5,133.2,132.1$, $599129.8,120.4$ (q, $J=320.0 \mathrm{~Hz}), 119.0,109.0,25.8,21.5$.

600 Bis(4-(tert-butyl)phenyl)iodonium Trifluoromethanesulfonate 601 (3al). ${ }^{22}$ GP3 was used on a $4 \mathrm{mmol}$ scale. Purification by 602 recrystallization in diethyl ether afforded the product as white needles 603 (1.52 g, 70\%): mp $163-165{ }^{\circ} \mathrm{C}$ (lit. $\left.{ }^{22} 164-165{ }^{\circ} \mathrm{C}\right) ;{ }^{1} \mathrm{H}$ NMR $(400$ $\left.604 \mathrm{MHz}, \mathrm{CDCl}_{3}\right) \delta 7.87-7.76(\mathrm{~m}, 4 \mathrm{H}), 7.43-7.36(\mathrm{~m}, 4 \mathrm{H}), 1.23(\mathrm{~s}$, $60518 \mathrm{H}) ;{ }^{13} \mathrm{C}\left\{{ }^{1} \mathrm{H}\right\}$ NMR $\left(101 \mathrm{MHz}, \mathrm{CDCl}_{3}\right) \delta 156.7,134.8,129.7,120.3$ $606(\mathrm{~d}, J=321.3 \mathrm{~Hz}), 109.4,35.3,31.0$.

607 Bis(2,5-dimethylphenyl)iodonium Trifluoromethanesulfonate 608 (3am). ${ }^{17 b}$ GP3 was used on a $5 \mathrm{mmol}$ scale. Purification by 609 recrystallization in diethyl ether afforded the product as brown solids 610 (896 mg, 46\%): mp 168-169 ${ }^{\circ} \mathrm{C}\left(\right.$ lit. $\left.^{11 \mathrm{~b}} 173-175^{\circ} \mathrm{C}\right) ;{ }^{1} \mathrm{H}$ NMR $(399$ $\left.611 \mathrm{MHz}^{\mathrm{CDCl}}\right)_{3} \delta 7.73(\mathrm{~s}, 2 \mathrm{H}), 7.33(\mathrm{~s}, 4 \mathrm{H}), 2.56(\mathrm{~s}, 6 \mathrm{H}), 2.34(\mathrm{~s}, 6 \mathrm{H})$; ${ }_{612}{ }^{13} \mathrm{C}\left\{{ }^{1} \mathrm{H}\right\} \mathrm{NMR}\left(100 \mathrm{MHz}, \mathrm{CDCl}_{3}\right) \delta 140.6,138.1,136.9,134.4,132.0$, 613 117.0, 25.1, 20.8 .

\section{ASSOCIATED CONTENT}

\section{S Supporting Information}

616 The Supporting Information is available free of charge on the 617 ACS Publications website at DOI: 10.1021/acs.joc.7b01346.

618 Description of reaction setups, optimization of reaction 619 conditions and enthalpy measurements and spectral data 620 of all products (PDF)

\section{AUTHOR INFORMATION}

\section{Corresponding Author}

${ }_{623}$ *E-mail: t.noel@tue.nl.

\section{ORCID $\odot$}

625 Volker Hessel: 0000-0002-9494-1519

626 Timothy Noël: 0000-0002-3107-6927

\section{Author Contributions}

$628{ }^{\dagger}$ G.L. and H.P.L.G. contributed equally to this work.

\section{Notes}

630 The authors declare no competing financial interest.

\section{ACKNOWLEDGMENTS}

632 Financial support is provided by the Dutch Science Foundation 633 (NWO) by an ECHO grant (Grant No. 713.013.001) and a 634 VIDI grant for T.N. (Grant No. 14150).

\section{REFERENCES}

636 (1) (a) Merritt, E. A.; Olofsson, B. Angew. Chem., Int. Ed. 2009, 48, 637 9052-9070. (b) Wirth, T. Angew. Chem., Int. Ed. 2005, 44, 3656638 3665. (c) Zhdankin, V. V.; Stang, P. J. Chem. Rev. 2002, 102, 25236392584
(2) (a) Aradi, K.; Tóth, B.; Tolnai, G.; Novák, Z. Synlett 2016, 27, 640 1456-1485. (b) Chan, L.; McNally, A.; Toh, Q. Y.; Mendoza, A.; 641 Gaunt, M. J. Chem. Sci. 2015, 6, 1277-1281. (c) Gonda, Z.; Novák, Z. 642 Chem. - Eur. J. 2015, 21, 16801-16806.

(3) (a) Gemoets, H. P. L.; Laudadio, G.; Verstraete, K.; Hessel, V.; 644 Noël, T. Angew. Chem., Int. Ed. 2017, 56, 7161-7165. (b) Sheng, J.; 645 Su, X.; Cao, C.; Chen, C. Org. Chem. Front. 2016, 3, 501-504. 646 (c) Duong, H. A.; Gilligan, R. E.; Cooke, M. L.; Phipps, R. J.; Gaunt, 647 M. J. Angew. Chem., Int. Ed. 2011, 50, 463-466. (d) Phipps, R. J.; 648 Gaunt, M. J. Science 2009, 323, 1593-1597. (e) Deprez, N. R.; 649 Sanford, M. S. Inorg. Chem. 2007, 46, 1924-1935. (f) Kalyani, D.; 650 Deprez, N. R.; Desai, L. V.; Sanford, M. S. J. Am. Chem. Soc. 2005, 127, 651 $7330-7331$.

652

(4) (a) Wagner, A. M.; Sanford, M. S. J. Org. Chem. 2014, 79, 2263- 653 2267. (b) Huang, X.; Zhu, Q.; Xu, Y. Synth. Commun. 2001, 31, 2823- 654 2828. 655

(5) Jalalian, N.; Ishikawa, E. E.; Silva, L. F.; Olofsson, B. Org. Lett. 656 2011, 13, 1552-1555.

(6) Sandtorv, A. H.; Stuart, D. R. Angew. Chem., Int. Ed. 2016, 55, 658 $15812-15815$.

(7) Xu, X.; Wang, D.; Ge, C.; Yu, X.; Wan, H. Synlett 2016, 27, 660 2616-2620.

(8) Reitti, M.; Villo, P.; Olofsson, B. Angew. Chem., Int. Ed. 2016, 55, 662 $8928-8932$.

(9) (a) Aggarwal, V. K.; Olofsson, B. Angew. Chem, Int. Ed. 2005, 44,66 5516-5519. (b) Wang, D.; Ge, B.; Li, L.; Shan, J.; Ding, Y. J. Org. 665 Chem. 2014, 79, 8607-8613. (c) Oh, C. H.; Kim, J. S.; Jung, H. H. J. 666 Org. Chem. 1999, 64, 1338-1340. (d) Chen, K.; Koser, G. F. J. Org. 667 Chem. 1991, 56, 5764-5767.

(10) (a) Qin, L.; Hu, B.; Neumann, K. D.; Linstad, E. J.; McCauley, 669 K.; Veness, J.; Kempinger, J. J.; DiMagno, S. G. Eur. J. Org. Chem. 670 2015, 2015, 5919-5924. (b) Watts, K.; Gattrell, W.; Wirth, T. Beilstein 671 J. Org. Chem. 2011, 7, 1108-1114. (c) Hossain, M. D.; Kitamura, T. 672 Tetrahedron 2006, 62, 6955-6960. (d) Carroll, M. A.; Pike, V. W.; 673 Widdowson, D. A. Tetrahedron Lett. 2000, 41, 5393-5396. 674 (e) Kaźmierczak, P.; Skulski, L. Synthesis 1995, 1995, 1027-1032. 675 (11) (a) Bielawski, M.; Olofsson, B. Chem. Commun. 2007, 2521- 676 2523. (b) Bielawski, M.; Zhu, M.; Olofsson, B. Adv. Synth. Catal. 2007, 677 349, 2610-2618.

(12) For a flow approach on reaction calorimetry, see: Glotz, G.; 679 Knoechel, D. J.; Podmore, P.; Gruber-Woelfler, H.; Kappe, C. O. Org. 680 Process Res. Dev. 2017, 21, 763-770.

(13) Peper-Bienzeisler, R.; Fickenfrerichs, H.; Jansen, W. CHEM- 682 KON 2012, 19, 21-28.

(14) Hallén, D. J. Chem. Thermodyn 1993, 25, 519-524. (15) Noël, T.; Su, Y.; Hessel, V. Top. Organomet. Chem. 2015, 57, 1- 685 41.

(16) (a) Kockmann, N.; Thenée, P.; Fleischer-Trebes, C.; Laudadio, 687 G.; Noel, T. React. Chem. Eng. 2017, 2, 258-280. (b) Gemoets, H. P. 688 L.; Su, Y.; Shang, M.; Hessel, V.; Luque, R.; Noel, T. Chem. Soc. Rev. 689 2016, 45, 83-117. (c) Movsisyan, M.; Delbeke, E. I. P.; Berton, J. K. 690 E. T.; Battilocchio, C.; Ley, S. V.; Stevens, C. V. Chem. Soc. Rev. 2016, 691 45, 4892-4928. (d) Gutmann, B.; Cantillo, D.; Kappe, C. O. Angew. 692 Chem., Int. Ed. 2015, 54, 6688-6728.

(17) (a) Kuhn, S.; Noël, T.; Gu, L.; Heider, P. L.; Jensen, K. F. Lab 694 Chip 2011, 11, 2488-2492. (b) Noël, T.; Naber, J. R.; Hartman, R. L.; 695 McMullen, J. P.; Jensen, K. F.; Buchwald, S. L. Chem. Sci. 2011, 2, 696 287-290.

(18) Pérez, J. M.; Cano, R.; McGlacken, G. P.; Ramón, D. J. RSC Adv. 698 2016, 6, 36932-36941.

(19) Kitamura, T.; Matsuyuki, J.-i.; Nagata, K.; Furuki, R.; Taniguchi, 700 H. Synthesis 1992, 1992, 945-946.

(20) Bigot, A.; Williamson, A. E.; Gaunt, M. J. J. Am. Chem. Soc. 702 2011, 133, 13778-13781.

(21) Sinai, Á.; Mészáros, Á.; Gáti, T.; Kudar, V.; Palló, A.; Novák, Z. 704 Org. Lett. 2013, 15, 5654-5657.

(22) Hossain, M. D.; Ikegami, Y.; Kitamura, T. J. Org. Chem. 2006, 706 71, 9903-9905. 